\title{
The Initiation and Enhancement of Human Red Cell Lysis by Activators of the First Component of Complement and by First Component Esterase; Studies Using Normal Red Cells and Red Cells from Patients with Parox- ysmal Nocturnal Hemoglobinuria *
}

\author{
Stanley Yachinin $\dagger$ and Janet M. Ruthenberg \\ (From the Argonne Cancer Research Hospital, $\$$ and the Department of Medicine, \\ University of Chicago, Chicago, Ill.)
}

Recent studies from this laboratory have described the anti- $\mathrm{C}^{\prime 1}$ properties of poly $\mathrm{I}(1,2)$. Inquiry into the mechanism by which poly $I$ inhibits $\mathrm{C}^{\prime}$-dependent immune hemolysis has revealed that this material interacts with the

\footnotetext{
* Submitted for publication July 31, 1964 ; accepted December 3, 1964.

This work was supported in part by the Helen and Joseph Regenstein Foundation.

† John and Mary R. Markle Scholar in Academic Medicine. Address requests for reprints to: Dr. Stanley Yachnin, Department of Medicine, The University of Chicago, 950 East 59th St., Chicago 37, Ill.

$\ddagger$ Operated by the University of Chicago for the United States Atomic Energy Commission.

1 The following abbreviations are used: $C^{\prime}$, complement ; anti- $\mathrm{C}^{\prime}$, anticomplementary; $\mathrm{C}^{\prime} \mathrm{H}_{50}, 50 \%$ hemolytic unit of complement; $C^{\prime} 1, C^{\prime} 2, C^{\prime} 3, C^{\prime} 4$, the first, second, third, or fourth component of complement; R1, R2, R3, $\mathrm{R} 4, \mathrm{RP}$, serum lacking the designated complement component or properdin; $\mathrm{C}^{\prime} 1 \mathrm{a}, \mathrm{C}^{\prime} 2 \mathrm{a}$, activated first or second complement components; $\mathrm{C}^{\prime} 1 \mathrm{q}, \mathrm{C}^{\prime} 1 \mathrm{~s}$, subcomponents of the first component of complement; $C^{\prime} 3 a, C^{\prime} 3 b, C^{\prime} 3 c, C^{\prime} 3 d$, four factors that together comprise total third component activity; $\mathrm{E}$, erythrocytes; $\mathrm{S}$, antigen site on the red cell membrane; A, antibody or amboceptor; EA, sensitized erythrocytes (usually sheep red cells); EAC'..., sensitized erythrocytes bearing complement components as designated by numerical subcripts; $E^{*}$, red cells irreversibly damaged by the action of complement; $\mathrm{S}^{*}$, red cell membrane site damaged by complement; $C^{\prime} 1 \mathrm{EI}$, the serum inhibitor of first component esterase; $\mathrm{PNH}$, paroxysmal nocturnal hemoglobinuria; PNHE, red cells from patients with paroxysmal nocturnal hemoglobinuria; NHE, normal human red cells; poly I, poly A, poly U, poly $\mathrm{C}$, biosynthetic homopolymers of inosinic, adenylic, uridylic, and cytidylic acids; poly $(I+A)$, poly $(I+C)$, double stranded hydrogen bonded helices composed of equimolar amounts of polyinosinic and polyadenylic acids or polyinosinic and polycytidylic acids; EDTA, ethylenediamine tetraacetate.
}

$C^{\prime} 1 q$ (11 S) (3) portion of the $C^{\prime} 1$ molecule, thereby preventing the attachment of $\mathrm{C}^{\prime} 1$ to the sensitized red cell (4). Addition of poly I to $\mathrm{C}^{\prime}$ also results in inactivation of $\mathrm{C}^{\prime} 4$. The latter effect is mediated via activation of the $\mathrm{C}^{\prime} 1$ molecule and the conversion of $C^{\prime} 1$ proesterase $\left(C^{\prime} 1 \mathrm{~s}\right)$ to the active esterase form (5). This conclusion, although based on indirect evidence, is strengthened by the observation that poly I shares with $\mathrm{C}^{\prime} 1 \mathrm{a}$ and purified $\mathrm{C}^{\prime} 1$ esterase the ability to evoke vascular permeability in guinea pig skin $(6,7)$. On the basis of this evidence an analogy has been drawn between the effects of poly I on the $\mathrm{C}^{\prime}$ system, and those of antigen-antibody complexes or heat aggregated gamma globulin $(5,6)$.

After having thus defined in detail the mechanism of poly I inhibition of immune red cell lysis, attention was turned to the effects of this material on the hemolysis in vitro of red cells from patients afflicted with $\mathrm{PNH}$. There can be little doubt that the $\mathrm{C}^{\prime}$ system participates in PNHE lysis, since removal or inactivation of any one of the four major components of $\mathrm{C}^{\prime}$ will destroy the capacity of human serum to support PNHE lysis (8). It was naturally anticipated that poly $\mathrm{I}$, being an anti-C ${ }^{\prime}$ substance, would inhibit the PNHE hemolytic system. In fact, it was found that the addition of poly I to human serum provoked substantial stimulation of PNHE hemolysis. In addition it was found that the addition of poly I to human serum could, under appropriate conditions, induce substantial in vitro hemolysis of normal human erythrocytes (NHE). Other activators of $\mathrm{C}^{\prime} 1$, as well as $C^{\prime} 1 a$ and $C^{\prime} 1$ esterase, behaved in a similar manner. This paper describes these hemolytic systems with respect to kinetics, $\mathrm{pH}$ optima, cat- 
ion requirements, and requirements for the participation of $\mathrm{C}^{\prime}$ components; offers a theory on the mechanism of the induction of a $\mathrm{C}^{\prime}$-dependent hemolytic system by "anticomplementary" substances via "indifferent" activation of fluid phase $\mathrm{C}^{\prime}$ components; and comments upon the possible significance of these phenomena in relationship to acquired hemolytic anemia in humans.

\section{Methods}

Polynucleotides. The methods of preparation or isolation of the polynucleotides have been described in detail (1). Polynucleotides were dissolved in unbuffered 0.15 $\mathrm{M} \mathrm{NaCl}$ at a concentration of $10 \mu$ moles $\mathrm{P}$ per $\mathrm{ml}$ and were stored frozen at $-20^{\circ} \mathrm{C}$.

Human serum reagents. Five hundred $\mathrm{ml}$ blood was removed from healthy donors in the postprandial state and stored without anticoagulant at $4^{\circ} \mathrm{C}$ overnight. The following morning the clotted blood was centrifuged, and the serum was collected, pooled according to $\mathrm{ABO}$ blood type, and frozen in $6-$ to $10-\mathrm{ml}$ portions at $-85^{\circ} \mathrm{C}$ in a mechanical freezer. Preliminary experiments involving both NHE and PNHE showed that the stimulation of in vitro hemolysis by poly I occurred without the participation of any antibodies directed against the red cell, i.e., that hemolysis could be provoked by poly I even if red cells and serum were from the same donor. Accordingly, serum and red cells were used without regard to major or minor red cell antigens, provided only that the cell-serum combination was compatible by the usual cross-matching techniques. It was convenient to utilize $A B \mathrm{Rh}^{+}$donors as the serum source, and therefore, after preliminary studies had defined the nature and reproducibility of the phenomena under study, large pools of serum from $\mathrm{AB} \mathrm{Rh}^{+}$donors were collected and frozen for future use.

Serum deficient in the various components of $C^{\prime}$ (9) and RP (10) were prepared by published procedures. If not used immediately after preparation, these serum reagents were also stored at $-85^{\circ} \mathrm{C}$. Heat inactivated serum was prepared by incubating serum at $56^{\circ} \mathrm{C}$ for 30 minutes.

Serum containing EDTA salts was prepared as follows: $\mathrm{Na}_{2} \mathrm{MgEDTA}$ or $\mathrm{Na}_{3} \mathrm{HEDTA}_{2}$ was dissolved in water, titrated to the desired $\mathrm{pH}$ (6.5 or 7.4), and diluted to a concentration of $0.15 \mathrm{M}$ that served as a stock solution. Sufficient EDTA solution was added to serum to obtain the desired EDTA concentration ( $c a$. $2 \times 10^{-2} \mathrm{M}$ ), and after standing at room temperature for 30 minutes the serum was employed as indicated. Control serum was diluted with an equivalent volume of 0.15 $\mathrm{M} \mathrm{NaCl}$.

Human red cells. Blood from both normal and $\mathrm{PNH}$ donors was drawn under aseptic conditions into either

2 Geigy Industrial Chemicals, Ardsley, N. Y. one-sixth volume ACD solution ${ }^{3}$ or into an equal volume of Alsevers solution, and was left at $4^{\circ} \mathrm{C}$. Most studies were done on cells that were less than 7 days old, but since the length of storage seemed to have little effect upon the susceptibility of the red cells to poly I-induced hemolysis (vide infra), cells were occasionally kept and used for up to 14 days. Before use the red cells were washed 3 times in $0.15 \mathrm{M} \mathrm{NaCl}$, and after the buffy coat had been carefully aspirated, they were suspended to $20 \%$ by volume in $0.15 \mathrm{M} \mathrm{NaCl}$.

\section{Other materials}

A. Gamma globulin aggregates. Soluble, heat aggregated, gamma globulin was prepared according to the method of Hinz and Mollner (11) with commercially obtained human $7 \mathrm{~S}$ gamma globulin as the starting material.4 The stock solution of heat aggregated gamma globulin in $0.15 \mathrm{M} \mathrm{NaCl}$ contained $43.0 \mathrm{mg}$ protein per $\mathrm{ml}$.

B. Antigen-antibody aggregates. Antiserum to bovine serum albumin was prepared in rabbits, cleared by high speed centrifugation, heated at $56^{\circ}$ for 30 minutes, and diluted $1: 2$ with $0.15 \mathrm{M} \mathrm{NaCl}$ containing $1.2 \times 10^{-2} \mathrm{M}$ $\mathrm{Na}_{3} \mathrm{HEDTA}$. This antiserum dilution was then mixed with an equal volume of bovine serum albumin solution containing $370 \mu \mathrm{g}$ protein per $\mathrm{ml}$ (an amount of antigen designed to yield an antigen-antibody precipitate formed at equivalence according to pretitration). The mixture was kept at $4^{\circ} \mathrm{C}$ for 48 hours, and the precipitate was then isolated by centrifugation, washed 3 times in 0.15 $\mathrm{M} \mathrm{NaCl}$, and finally suspended in saline at a protein concentration of $30.9 \mathrm{mg}$ per ml.

C. Streptokinase. ${ }^{5}$ This enzyme was dissolved in 0.15 $\mathrm{M} \mathrm{NaCl}$ at a concentration of $10,000 \mu$ per $\mathrm{ml}$ and was stored at $-85^{\circ} \mathrm{C}$.

D. Dextran sulfate. ${ }^{6}$ Two dextran sulfates of mean molecular weights $60,000(60 \mathrm{~S})$ and $200,000(200 \mathrm{~S})$ were dissolved in $0.15 \mathrm{M} \mathrm{NaCl}$ at a concentration of $5,000 \mu \mathrm{g}$ per $\mathrm{ml}$ and kept at $4^{\circ} \mathrm{C}$.

E. Partially purified $C^{\prime} 1 a$. Two separate preparations of human $C^{\prime} 1$ were prepared by the method of Lepow, Ratnoff, Rosen, and Pillemer (12). Before use the material was activated as described by the same authors. The activated preparations contained 48 and $37.6 \mathrm{U} \mathrm{C}^{\prime} 1$ esterase per $\mathrm{ml}(13)$.

F. $C^{\prime} 1$ esterase. $C^{\prime} 1$ esterase was isolated by DEAE ion exchange resin chromatography of a human serum euglobulin fraction as outlined by Haines and Lepow (14). Only the first resin passage was performed. The fractions containing esterase activity were pooled, dialyzed against ion free water, and dissolved in $0.15 \mathrm{M}$ $\mathrm{NaCl}$. The final preparation, containing $352 \mathrm{U}^{\prime} 1$ esterase and $2 \mathrm{mg}$ protein per $\mathrm{ml}$, was stored at $-85^{\circ} \mathrm{C}$.

G. C'1 esterase serum inhibitor. This material, iso-

3 Vacutainers, Becton Dickinson and Co., Columbus, Neb.

4 Pentex Laboratories, Kankakee, Ill.

5 Varidase, Lederle Laboratories, Pearl River, N. Y.

${ }^{6}$ Sigma Chemical Co., St. Louis, Mo. 
lated by the method of Pensky, Levy, and Lepow (15), was dissolved in $0.15 \mathrm{M} \mathrm{NaCl}$. The stock solution, stored frozen at $-85^{\circ} \mathrm{C}$, contained $11.7 \mathrm{U} \mathrm{C} 1 \mathrm{EI}$ per $\mathrm{ml}$ (13).

Estimation of in vitro hemolysis. The technique used in estimating red cell hemolysis was similar to that described in a previous publication on $\mathrm{pH}$-dependent hemolytic systems (16). The basic system consisted of $1 \mathrm{ml}$ human serum or human serum reagent, a precisely measured volume of test substance dissolved in unbuffered $0.15 \mathrm{M} \mathrm{NaCl}$ (usually $0.1 \mathrm{ml}$ ) ${ }^{7}$ or an equivalent volume of saline only as a control, and $0.05 \mathrm{ml}$ of a $20 \%$ suspension of erythrocytes. If the $\mathrm{pH}$ had been lowered from that of the native thawed serum, the serum was kept under oil until completion of the experiment. All reagents were prewarmed to $37^{\circ} \mathrm{C}$ before mixing, and hemolysis was carried out at the same temperature for 30 minutes with occasional gentle agitation to keep the cells evenly suspended. The tubes were then centrifuged, and the supernatant fluid was removed with a Pasteur pipette. The optical density of the supernatant fluid at $540 \mathrm{~m} \mu$ was measured against an appropriate serum blank in matched silica cuvettes with a 1-cm light path. The per cent hemolysis was determined by comparison with a cell-serum sample that had been completely hemolyzed by freezing and thawing. The $100 \%$ OD at $540 \mathrm{~m} \mu$ of $0.05 \mathrm{ml}$ cell suspension in the usual test volume $(1.15 \mathrm{ml})$ ranged from 1.3 to 2.1 ; the lower values were observed with $\mathrm{PNHE}$, presumably because of their lower mean corpuscular hemoglobin concentration (17).

The $\mathrm{pH}$ of serum immediately after thawing was generally 7.5 to 7.7. Serum was acidified directly before use by titration with small amounts of $0.3 \mathrm{~N} \mathrm{HCl}$ and was kept under oil at $4^{\circ} \mathrm{C}$ until needed. All $\mathrm{pH}$ values refer to measurements taken before incubation at $37^{\circ} \mathrm{C}$; it is recognized that $\mathrm{pH}$ values increase by approximately $0.5 \mathrm{pH} \mathrm{U}$ after 30 minutes incubation at $37^{\circ} \mathrm{C}$ (18).

During the initial phases of this study variable results were obtained when attempts were made to reproducibly increase or initiate hemolysis by poly I addition to serum. This variability revealed the critical importance of the sequence and timing of the various additions to the hemo-

\footnotetext{
7 Upon the addition of $>0.5 \mu$ mole poly I to $1 \mathrm{ml}$ whole human serum $(\mathrm{pH}$ 6.5) an immediate haze appeared. Preliminary study of the easily centrifuged precipitate revealed the presence of poly I and protein. A similar haze was not provoked by other polynucleotides, nor by poly $(I+A)$ or poly $(I+C)$, nor would poly I evoke precipitate formation in heated serum or R1. Precipitate formation has been observed in $\mathrm{R} 2$ and in $\mathrm{Na}_{3} \mathrm{HEDTA}$ chelated serum. The nature of the proteins precipitated by poly I is presently under investigation; gamma globulin has been identified as being present in the precipitate. A similar precipitate is formed with the addition of $>125 \mu \mathrm{g}$ dextran solution to $1 \mathrm{ml}$ serum. Since the precipitate was easily brought down during centrifugation, it did not interfere with optical density determinations on the supernatant during hemolysis experiments.
}

lytic system. For reproducible results it is imperative that the addition of erythrocytes and test material be, for all practical purposes, simultaneous; the ability of test material to initiate or provoke hemolysis diminishes in minutes if test material and serum are preincubated at $37^{\circ} \mathrm{C}$ before the addition of cells. In addition (in the case of PNHE hemolysis) with the further passage of time such a test material-serum mixture gradually loses hemolytic capacity (vide infra). Since actual simultaneous addition was not practical, preaddition of cells, mixing, and subsequent addition of the other constituent was employed. This procedure took less than 15 seconds; it was considered, in the time lapse experiments, to be the "zero" time sample. Unless otherwise noted all results described are derived from this modified technique. All experiments were performed at least twice; all data reported have been verified as reproducible.

In addition to the importance of the time and sequence of addition of test materials in these hemolytic systems, dilution of serum was found to be critical. Thus, in experiments with the $R$ reagents, where such reagents as $\mathrm{R} 1$ and R4 were appreciably diluted with respect to the original serum (dilutions of $1: 1.25$ and $1: 1.45$, respectively), it was imperative to include appropriate saline diluted control serum tests in order to assess fairly the effect of the specific $C^{\prime}$ component depletion upon the hemolytic systems. The point will be more fully discussed in the following section.

Protein determinations were done by a modified Folin technique (19). A Beckman Zerostatic pH meter and Zeiss PMQ II spectrophotometer were used throughout.

\section{Results}

Table I shows the effects of the addition of 1.0 $\mu$ mole $\mathrm{P}$ poly $\mathrm{I}$ to the hemolytic system using red cells from $10 \mathrm{PNH}$ patients and 12 normal individuals. NHE undergo less than $10 \%$ hemolysis with poly I addition at $\mathrm{pH} 7.6$; $\mathrm{PNHE}$, on the other hand, consistently show $>30 \%$ hemolysis at this $\mathrm{pH}$ in the presence of poly $\mathrm{I}$, even if, in the $\mathrm{pH} 7.6$ control, they display little or no lytic susceptibility. At $\mathrm{pH} 6.5$ all cells show substantial hemolysis in the presence of poly I. PNHE, which invariably hemolyze appreciably at this $\mathrm{pH}$, are hemolyzed 2 to 3 times more effectively as a result of poly I addition. NHE, which in the absence of poly I are incapable of hemolysis even at $\mathrm{pH} 6.5$, in its presence display levels of hemolytic susceptibility comparable to those of PNHE in the $\mathrm{pH} 6.5$ saline controls. Hemolytic tests using the red cells of a large variety of hospital patients with and without hematologic disease have failed to detect any individual whose cells are resistant to hemolysis at $\mathrm{pH} 6.5$ 
TABLE I

Effect of poly I on hemolysis of PNH and normal erythrocytes*

\begin{tabular}{|c|c|c|c|c|c|c|c|c|c|}
\hline \multirow[b]{3}{*}{ Patient } & \multicolumn{4}{|c|}{ PNH } & \multirow[b]{3}{*}{ Patient } & \multicolumn{4}{|c|}{ Normal } \\
\hline & \multicolumn{2}{|c|}{ pH 7.6} & \multicolumn{2}{|c|}{$\mathrm{pH} 6.5$} & & \multicolumn{2}{|c|}{$\mathrm{pH} 7.6$} & \multicolumn{2}{|c|}{$\mathrm{pH} 6.5$} \\
\hline & $\begin{array}{l}\text { Saline } \\
\text { control }\end{array}$ & Poly I & $\begin{array}{l}\text { Saline } \\
\text { control }\end{array}$ & Poly I & & $\begin{array}{l}\text { Saline } \\
\text { control }\end{array}$ & Poly I & $\begin{array}{c}\text { Saline } \\
\text { control }\end{array}$ & Poly I \\
\hline & \multicolumn{2}{|c|}{ \% lysis } & \multicolumn{2}{|c|}{ \% lysis } & & \multicolumn{2}{|c|}{ \% lysis } & \multicolumn{2}{|c|}{ \% lysis } \\
\hline $\begin{array}{r}1 \\
2 \\
3 \\
4 \\
5 \\
6 \\
7 \\
8 \\
9 \\
10\end{array}$ & $\begin{array}{r}5 \\
8 \\
5 \\
11 \\
25 \\
2 \\
9 \\
9 \\
8 \\
11\end{array}$ & $\begin{array}{l}31 \\
61 \\
49 \\
61 \\
57 \\
64 \\
59 \\
78 \\
43 \\
71\end{array}$ & $\begin{array}{l}22 \\
36 \\
30 \\
53 \\
43 \\
41 \\
37 \\
47 \\
20 \\
32\end{array}$ & $\begin{array}{r}66 \\
92 \\
80 \\
82 \\
76 \\
84 \\
63 \\
65 \\
95 \\
66 \\
86\end{array}$ & $\begin{array}{r}1 \\
2 \\
3 \\
4 \\
5 \\
6 \\
7 \\
8 \\
9 \\
10 \\
11 \\
12\end{array}$ & $\begin{array}{l}1 \\
1 \\
1 \\
0 \\
2 \\
1 \\
1 \\
2 \\
2 \\
1 \\
1 \\
1\end{array}$ & $\begin{array}{l}5 \\
0 \\
5 \\
1 \\
4 \\
2 \\
3 \\
2 \\
2 \\
2 \\
2 \\
1\end{array}$ & $\begin{array}{l}1 \\
1 \\
1 \\
1 \\
1 \\
1 \\
3 \\
2 \\
3 \\
2 \\
3 \\
2\end{array}$ & $\begin{array}{l}48 \\
28 \\
42 \\
37 \\
43 \\
27 \\
59 \\
38 \\
40 \\
36 \\
46 \\
36\end{array}$ \\
\hline Range & $2-25$ & $31-78$ & $20-53$ & $63-95$ & & $0-2$ & $0-5$ & $1-3$ & $27-59$ \\
\hline
\end{tabular}

* $\mathrm{PNH}=$ paroxysmal nocturnal hemoglobinuria.

in the presence of poly I. Although there is little or no overlap in the range of poly I-induced hemolysis at $\mathrm{pH} 6.5$ when $\mathrm{NHE}$ (27 to $59 \%$ ) and PNHE (63 to $95 \%$ ) are compared, an occasional test with NHE under these conditions has resulted in $>60 \%$ hemolysis (for example, see Table V). From these data it is apparent that the poly I-induced hemolytic system will invariably distinguish between PNHE and NHE at pH 7.6.

Other polynucleotides. The following naturally occurring and synthetic polynucleotides were studied for their ability to induce NHE hemolysis or to provoke PNHE hemolysis: RNA derived from rat liver, guinea pig liver, and mouse spleen; poly $A$, poly U, poly $\mathrm{C}$; and apurinic acid derived from calf thymus DNA. One $\mu$ mole $\mathrm{P}$ of these materials fails to induce or provoke an increase in NHE or PNHE hemolysis at either $\mathrm{pH}$ 6.5 or 7.6 .

Effect of hydrogen bonded helix formation upon the capacity of poly I to provoke hemolysis. Poly $(\mathrm{I}+\mathrm{C})$ and poly $(\mathrm{I}+\mathrm{A})$ are incapable of stimulating PNHE hemolysis. In addition, poly I incorporated into such helices is incapable of inducing $\mathrm{NHE}$ hemolysis.

Effect of increments of poly I upon poly I-induced hemolysis. Figure 1 illustrates the ability of varying amounts of poly I to stimulate hemolysis of $\mathrm{NHE}$ and PNHE. Maximal enhancement of PNHE hemolysis is obtained with addition of
$0.6 \mu$ mole $\mathrm{P}$ poly $\mathrm{I}$ at both $\mathrm{pH} 7.6$ and $\mathrm{pH} 6.5$. Eight-tenths $\mu$ mole $\mathrm{P}$ poly I yields maximal NHE hemolysis in acidified serum. With larger amounts of poly I there is a slight but definite reduction in hemolysis in all instances. Despite this, and largely in an attempt to keep experimental conditions consistent with those in use before these observations, we continued to use 1 $\mu$ mole $\mathrm{P}$ poly I as the standard test dose in most of the experiments.

Other test materials. Dextran sulfate, $\mathrm{C}^{\prime} 1 \mathrm{a}, \mathrm{C}^{\prime} 1$

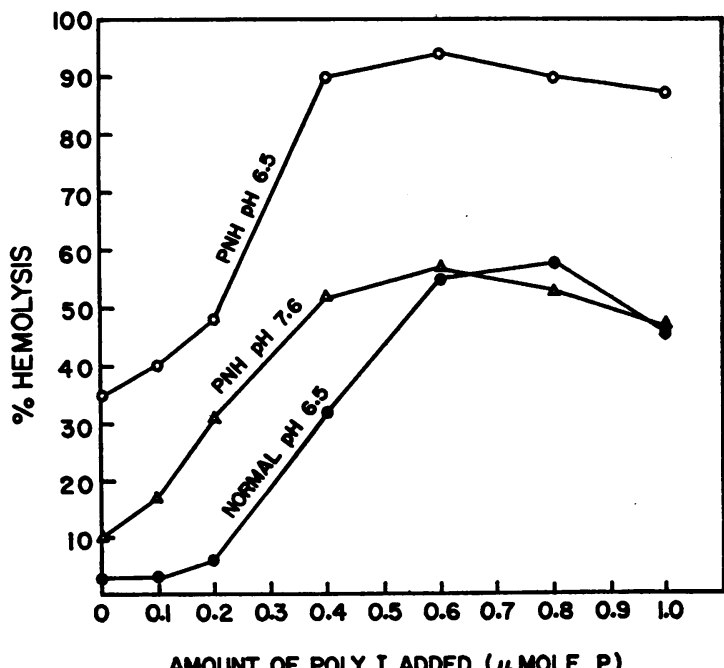

Fic. 1. ABILITY of INCREMENTS OF POLY I to INDUCE OR ENBANCE HEMOLYSIS. 
esterase, streptokinase, and aggregated $\gamma$-globulin all share with poly I the capacity to enhance hemolysis of PNHE, although none is as efficient as poly I (Table II). The dose dependency of this effect, with large doses of test material being inhibitory, is strikingly illustrated by dextran sulfate, $C^{\prime} 1$ esterase, and aggregated $\gamma$-globulin. Dextran sulfate is the only other test material capable of provoking $\mathrm{NHE}$ lysis, and here too its effect is less pronounced than that of the polynucleotide.

Effect of $p H$ upon test material induced hemolysis. As noted in Table I, poly I-induced hemolysis proceeds more effectively at $\mathrm{pH} 6.5$ than at $\mathrm{pH}$
7.6. Figure $2 \mathrm{~A}$ illustrates more completely the effects of variations in $\mathrm{pH}$ upon the ability of both PNHE and NHE to hemolyze in the presence and absence of poly I. NHE are resistant to hemolysis at all $\mathrm{pH}$ 's tested ; in the presence of poly I, optimal hemolysis of $\mathrm{NHE}$ occurs at $\mathrm{pH} 6.5$ to 6.8. PNHE, as expected, display maximal hemolysis at $\mathrm{pH} 6.2$ to 6.5 , and poly I enhancement results in maximal total hemolysis also at $\mathrm{pH} 6.5$. The greatest relative increase in PNHE hemolysis with poly I addition occurs at $\mathrm{pH} 7.6$, when hemolysis is increased to six times the control level. Similar results were obtained with dextran sulfate (Figure 2A) and in the case of PNHE with

TABLE II

Ability of increments of various test materials to induce or enhance human red cell lysis

\begin{tabular}{|c|c|c|c|c|c|c|c|c|}
\hline \multirow{3}{*}{$\begin{array}{l}\text { C'1a PNH cells } \\
\text { Esterase units added } \\
\text { (in } 0.4 \mathrm{ml} \text { saline) }\end{array}$} & \multicolumn{4}{|c|}{ Case PE } & \multicolumn{4}{|c|}{ Case ST } \\
\hline & \multicolumn{2}{|c|}{ pH 6.5} & \multicolumn{2}{|c|}{$\mathrm{pH} 7.6$} & \multicolumn{2}{|c|}{ pH 6.5} & \multicolumn{2}{|c|}{ pH 7.6} \\
\hline & $\begin{array}{l}\text { OD } \\
540\end{array}$ & $\begin{array}{c}\% \\
\text { lysis }\end{array}$ & $\begin{array}{l}\text { OD } \\
540\end{array}$ & $\begin{array}{c}\% \\
\text { lysis }\end{array}$ & $\begin{array}{l}\text { OD } \\
540\end{array}$ & $\begin{array}{c}\% \\
\text { lysis }\end{array}$ & $\begin{array}{l}\text { OD } \\
540\end{array}$ & $\begin{array}{c}\% \\
\text { lysis }\end{array}$ \\
\hline $\begin{array}{l}9.6 \\
4.8 \\
2.4 \\
1.2 \\
0.6 \\
0.3\end{array}$ & $\begin{array}{l}1.169 \\
1.034 \\
1.009 \\
0.860 \\
0.805 \\
0.780\end{array}$ & $\begin{array}{l}52.5 \\
46.5 \\
45 \\
39 \\
36 \\
35\end{array}$ & $\begin{array}{l}0.070 \\
0.154 \\
0.185 \\
0.137 \\
0.162 \\
0.113\end{array}$ & $\begin{array}{l}3.1 \\
6.9 \\
8.3 \\
6.1 \\
7.3 \\
5.1\end{array}$ & $\begin{array}{l}1.020 \\
0.939 \\
0.940 \\
0.731 \\
0.606 \\
0.631\end{array}$ & $\begin{array}{l}48 \\
44 \\
44 \\
34.5 \\
28.5 \\
30\end{array}$ & $\begin{array}{l}0.115 \\
0.203 \\
0.152 \\
0.133 \\
0.081 \\
0.087\end{array}$ & $\begin{array}{l}5.4 \\
9.6 \\
7.2 \\
6.3 \\
3.8 \\
4.1\end{array}$ \\
\hline $\begin{array}{l}\text { Control } \\
100 \%\end{array}$ & $\begin{array}{l}0.739 \\
2.23\end{array}$ & 33 & 0.098 & 4.4 & $\begin{array}{l}0.594 \\
2.12\end{array}$ & 28 & 0.089 & 4.2 \\
\hline
\end{tabular}

\begin{tabular}{|c|c|c|c|c|c|c|c|c|c|c|}
\hline \multirow{3}{*}{$\begin{array}{l}\text { C'1 esterase } \\
\text { PNH cells } \\
\text { Esterase units } \\
\text { added }\end{array}$} & \multicolumn{10}{|c|}{ pH 6.5} \\
\hline & \multicolumn{2}{|c|}{ Case 4} & \multicolumn{2}{|c|}{ Case 5} & \multicolumn{2}{|c|}{ Case 7} & \multicolumn{2}{|c|}{ Case 8} & \multicolumn{2}{|c|}{ Case PE } \\
\hline & $\begin{array}{l}\mathrm{OD} \\
540\end{array}$ & $\begin{array}{c}\% \\
\text { lysis }\end{array}$ & $\begin{array}{l}\text { OD } \\
540\end{array}$ & $\begin{array}{c}\% \\
\text { lysis }\end{array}$ & OD & $\begin{array}{c}\% \\
\text { lysis }\end{array}$ & OD & $\begin{array}{c}\% \\
\text { lysis }\end{array}$ & OD & $\begin{array}{c}\% \\
\text { lysis }\end{array}$ \\
\hline $\begin{array}{r}1 \\
2 \\
3 \\
4 \\
6 \\
10 \\
15 \\
30\end{array}$ & $\begin{array}{l}1.112 \\
1.623 \\
1.960 \\
2.02 \\
2.14 \\
1.512 \\
0.970\end{array}$ & $\begin{array}{l}48.8 \\
71.3 \\
86 \\
88.6 \\
94 \\
66.4 \\
42.5\end{array}$ & $\begin{array}{l}0.940 \\
1.023 \\
1.241 \\
1.277 \\
1.324 \\
1.230 \\
0.409\end{array}$ & $\begin{array}{l}68.5 \\
74.5 \\
90.5 \\
93 \\
96.5 \\
89.5 \\
\\
29.7\end{array}$ & $\begin{array}{l}0.639 \\
1.023 \\
1.178 \\
1.305 \\
1.234 \\
0.708 \\
0.461\end{array}$ & $\begin{array}{l}33.2 \\
53.2 \\
61.2 \\
67.8 \\
64.2 \\
36.8 \\
23.9\end{array}$ & $\begin{array}{l}0.370 \\
0.530 \\
0.588 \\
0.629 \\
0.613 \\
0.621 \\
0.501\end{array}$ & $\begin{array}{l}19.4 \\
27.8 \\
30.8 \\
32.9 \\
32.1 \\
32.5 \\
26.2\end{array}$ & $\begin{array}{l}0.538 \\
0.629 \\
0.700 \\
0.724 \\
0.715 \\
0.700 \\
0.625\end{array}$ & $\begin{array}{l}32.4 \\
38.5 \\
42 \\
43.5 \\
43 \\
42 \\
38\end{array}$ \\
\hline $\begin{array}{l}\text { Control } \\
100 \%\end{array}$ & $\begin{array}{l}0.925 \\
2.28\end{array}$ & 40.6 & $\begin{array}{l}0.805 \\
1.376\end{array}$ & 58.5 & $\begin{array}{l}0.474 \\
1.925\end{array}$ & 24.6 & $\begin{array}{l}0.280 \\
1.910\end{array}$ & 14.7 & $\begin{array}{l}0.470 \\
1.658\end{array}$ & 28 \\
\hline \multirow{2}{*}{\multicolumn{2}{|c|}{$\begin{array}{l}\text { Streptokinase PNH cells } \\
\text { Units added }\end{array}$}} & \multicolumn{3}{|c|}{ pH 6.5} & \multirow{2}{*}{\multicolumn{3}{|c|}{$\begin{array}{c}\text { Aggregated } \gamma \text {-globulin } \\
\text { PNH cells } \\
\mu \mathrm{g} \text { added }\end{array}$}} & \multicolumn{3}{|c|}{ pH 6.5} \\
\hline & & \multicolumn{2}{|l|}{ OD 540} & $\%$ lysis & & & & OD 540 & \multicolumn{2}{|c|}{$\%$ lysis } \\
\hline \multirow{2}{*}{\multicolumn{2}{|c|}{$\begin{array}{r}1,000 \\
500 \\
100 \\
50\end{array}$}} & \multirow[b]{2}{*}{$\begin{array}{l}0.865 \\
1.008 \\
1.196 \\
1.341\end{array}$} & \multirow{2}{*}{\multicolumn{2}{|c|}{$\begin{array}{l}46 \\
54 \\
64 \\
72\end{array}$}} & \multirow{3}{*}{\multicolumn{2}{|c|}{$\begin{array}{r}4,300 \\
43 \\
21.5 \\
14.3 \\
10.8 \\
8.6\end{array}$}} & & \multirow{3}{*}{$\begin{array}{l}0.002 \\
0.451 \\
0.875 \\
0.960 \\
1.051 \\
0.985\end{array}$} & \multirow{3}{*}{\multicolumn{2}{|c|}{$\begin{array}{l}0 \\
29 \\
46.5 \\
51 \\
56 \\
53\end{array}$}} \\
\hline & & & & & & & & & & \\
\hline \multirow{2}{*}{$\begin{array}{l}\text { Control } \\
100 \%\end{array}$} & & \multirow{2}{*}{$\begin{array}{l}0.800 \\
1.870\end{array}$} & \multicolumn{2}{|r|}{42} & & & & & & \\
\hline & & & & & \multicolumn{2}{|c|}{$\begin{array}{l}\text { Control } \\
100 \%\end{array}$} & & $\begin{array}{l}1.838 \\
1.870\end{array}$ & \multicolumn{2}{|c|}{44} \\
\hline
\end{tabular}




\begin{tabular}{|c|c|c|c|c|c|c|}
\hline \multirow{4}{*}{$\begin{array}{l}\text { Dextran sulfate } \\
\mu \mathrm{g} \text { added }\end{array}$} & \multicolumn{6}{|c|}{ pH 6.5} \\
\hline & \multirow{2}{*}{\multicolumn{2}{|c|}{$\frac{\text { Dextran sulfate } 60 \mathrm{~S}}{\text { PNH cells }}$}} & \multicolumn{4}{|c|}{ Dextran sulfate $200 \mathrm{~S}$} \\
\hline & & & \multicolumn{2}{|c|}{ PNH cells } & \multicolumn{2}{|c|}{ Normal cells } \\
\hline & OD 540 & $\%$ lysis & OD 540 & \% lysis & OD 540 & $\%$ lysis \\
\hline $\begin{array}{c}500 \\
250 \\
125 \\
62.5 \\
31 \\
16 \\
8\end{array}$ & $\begin{array}{l}0.044 \\
1.460 \\
1.490 \\
1.280 \\
0.980 \\
0.850 \\
0.805\end{array}$ & $\begin{array}{r}2.2 \\
73.8 \\
75.4 \\
64.6 \\
49.4 \\
42.8 \\
40.6\end{array}$ & $\begin{array}{l}.880 \\
1.575 \\
1.660 \\
1.310 \\
0.965 \\
0.770 \\
0.750\end{array}$ & $\begin{array}{l}43 \\
77 \\
81 \\
64 \\
47 \\
37.6 \\
36.6\end{array}$ & $\begin{array}{c}0 \\
0.207 \\
0.363 \\
0.055 \\
0.006 \\
0.006 \\
0.010\end{array}$ & $\begin{array}{c}0 \\
9.7 \\
17.0 \\
2.6 \\
0 \\
0 \\
0.05\end{array}$ \\
\hline $\begin{array}{l}\text { Control } \\
100 \%\end{array}$ & $\begin{array}{l}0.800 \\
1.980\end{array}$ & 40.3 & $\begin{array}{l}0.740 \\
2.05\end{array}$ & $\begin{array}{l}36 \\
91\end{array}$ & $\begin{array}{l}0.002 \\
2.13\end{array}$ & 0 \\
\hline
\end{tabular}

\begin{tabular}{|c|c|c|c|c|c|}
\hline \multirow[b]{3}{*}{ Reagent } & \multicolumn{3}{|c|}{ Simultaneous test of all reagents $-\mathrm{pH} 6.5$} & \multirow{2}{*}{\multicolumn{2}{|c|}{ Normal cells }} \\
\hline & & \multicolumn{2}{|c|}{ PNH cells } & & \\
\hline & Amount & OD 540 & \% lysis & OD 540 & \% lysis \\
\hline $\begin{array}{l}\text { Poly I } \\
\text { Dextran sulfate } \\
\text { C'1 esterase } \\
\text { Streptokinase } \\
\text { Aggregated } \gamma \text {-globulin }\end{array}$ & 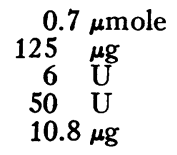 & $\begin{array}{l}1.750 \\
1.480 \\
0.900 \\
0.772 \\
0.754\end{array}$ & $\begin{array}{l}90.6 \\
76.6 \\
46.6 \\
40 \\
39\end{array}$ & $\begin{array}{l}1.123 \\
0.354 \\
0.010 \\
0.000 \\
0.010\end{array}$ & $\begin{array}{l}53 \\
16.7 \\
0.4 \\
0 \\
0.4\end{array}$ \\
\hline $\begin{array}{l}\text { Control } \\
100 \%\end{array}$ & & $\begin{array}{l}0.680 \\
1.930\end{array}$ & 35.2 & $\begin{array}{l}0.000 \\
2.120\end{array}$ & 0 \\
\hline
\end{tabular}

$\mathrm{C}^{\prime} 1 \mathrm{a}, \mathrm{C}^{\prime} 1$ esterase, streptokinase, and aggregated $\gamma$-globulin (Figure 2B, Table II).

Effect of pre-exposure of red cells to test material upon their lytic susceptibility. Certain agents capable of altering the red cell membrane are able to render NHE susceptible to $\mathrm{C}^{\prime}$-dependent hemolysis in acidified human serum (16). In addition, red cells coated by antigen are susceptible to $\mathrm{C}^{\prime}$-dependent hemolysis in the presence of specific antibody (20). Experiments were performed to investigate the possibility that poly I-induced hemolysis might share a similar mechanism, i.e., that poly I was altering, sensitizing, or attaching to the red cell surface in a manner analogous to the action of influenza virus, proteolytic enzymes, neuraminidase, periodate ions, tannic acid (21), or "antigen." One-tenth $\mathrm{ml}$ of a $20 \%$ suspension of PNHE or NHE was exposed to $0.5 \mathrm{ml}$ poly I solution $(10 \mu$ moles and $4 \mu$ moles $\mathrm{P}$ per $\mathrm{ml}$ ) at $37^{\circ} \mathrm{C}$ for 30 minutes. After washing 3 times in $0.15 \mathrm{M} \mathrm{NaCl}$, they were subjected to hemolysis in human serum at $\mathrm{pH} 6.5$ and compared with control cells exposed to saline solution only. There is no change in the susceptibility of PNHE to hemolysis after pre-exposure to poly I, nor do NHE develop any hemolytic properties after such treatment. Similar results were obtained using dextran sulfate $(1,250 \mu \mathrm{g}$ per $\mathrm{ml})$, $\mathrm{C}^{\prime} 1$ esterase ( $60 \mathrm{U}$ per $\mathrm{ml}$ ), aggregated $\gamma$-globulin (108 $\mu \mathrm{g}$ per $\mathrm{ml}$ ), and streptokinase (500 U per $\mathrm{ml}$ ). Thus the mechanism by which these materials provoke or enhance hemolysis does not depend on their ability to attach to, alter, or sensitize the red cell membrane; this implies that an explanation for their mechanism of action should be sought in relation to their effect upon serum factors involved in red cell lysis.

Effect of pre-exposure of serum to test material upon the capacity of test material to induce or enhance hemolysis. During the initial phase of these studies poly I occasionally failed to stimulate PNHE hemolysis. It was finally appreciated that this failure occurred whenever poly I and serum had been in contact for an extended period before addition of cells. Only after the need for simultaneous addition of poly I and red cells had been appreciated was the ability of poly I to provoke substantial hemolysis of $\mathrm{NHE}$ at $\mathrm{pH} 6.5$ first recognized. The experiments defining the kinetics of both hemolytic systems with the passage of time between poly I and red cell addition to serum are shown in Figure 3. At pH 6.5 the ability of poly 

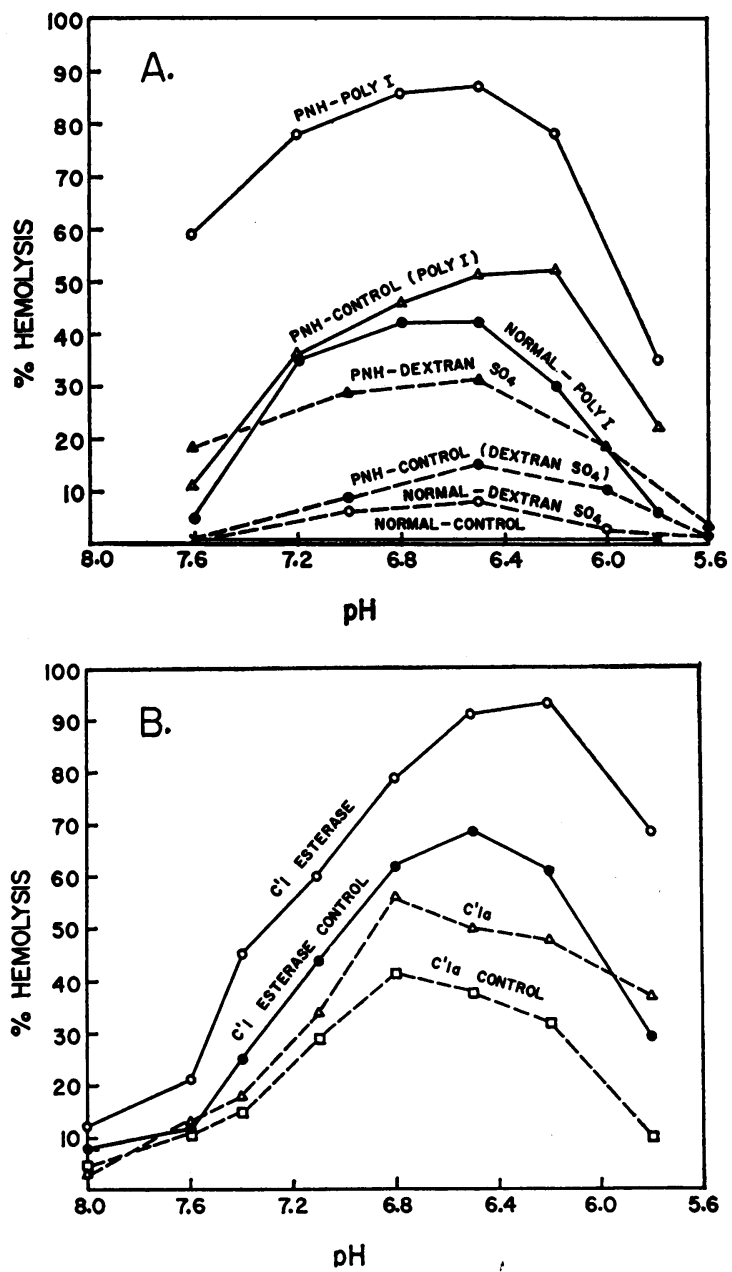

Fig. 2A. EFFECT OF PH UPON POLY I AND DEXTRAN SULFATE-INDUCED LYSIS. $1.0 \mu$ mole poly I or $125 \mu \mathrm{g}$ dextran sulfate was employed. B. EFFECT of $\mathrm{PH}$ UPON $\mathrm{C}^{\prime} 1 \mathrm{~A}$ AND C'1 eSTERASE ENHANCEMENT OF PNH RED CELL HeMolysis. Six $U C^{\prime} 1$ esterase $(0.1 \mathrm{ml})$ and $9.6 \mathrm{U} \mathrm{C}^{\prime} 1 \mathrm{a}$ $(0.4 \mathrm{ml})$ were employed. $\mathrm{PNH}=$ paroxysmal nocturnal hemoglobinuria.

I to enhance PNHE hemolysis is lost after 10 minutes preincubation, and thereafter the serumpoly I mixture gradually loses all ability to sustain PNHE hemolysis, total inhibition occurring at 45 minutes. At $\mathrm{pH} 7.6$, although the degree of hemolysis is initially less than at $\mathrm{pH} 6.5$, the rate of decline of poly I enhancement is much slower. The hemolytic system involving NHE is most sensitive to the duration of poly I-serum preincubation; by 8 minutes practically all hemolytic capacity has been lost. Similar results were obtained with the other test materials (Table III).
Effect of serum dilution upon poly I-induced hemolysis. The PNH hemolytic system is known to be highly sensitive to serum dilution (22). Figure 4 demonstrates that poly I enhancement of PNHE hemolysis is also destroyed by a $1: 4$ dilution of serum both at $\mathrm{pH} 6.5$ and 7.6. The induction of NHE hemolysis by poly I is even more sensitive to serum dilution, being abolished almost totally by a $1: 1.6$ dilution of serum. Similar results, in the case of PNHE hemolysis, were obtained using $\mathrm{C}^{\prime} 1$ esterase (Table IV).

Effect of red cell storage upon susceptibility to poly I-induced hemolysis. Certain red cell agglutinins are known to attack preferentially cells that have been stored for prolonged periods of time in vitro (23). NHE kept aseptically in ACD solution for 4 weeks at $4^{\circ} \mathrm{C}$ were repeatedly tested for their susceptibility to poly I-induced hemolysis using a single serum pool. Little, if any, increase in hemolytic susceptibility is noted with time (Table V).

Effect of EDTA salts upon poly I-induced hemolysis. PNHE hemolysis is known to be dependent on $\mathrm{Mg}^{++}$, but $\mathrm{Ca}^{++}$ion is not required (8). $\mathrm{Na}_{3}$ HEDTA (which binds both $\mathrm{Ca}^{++}$and $\mathrm{Mg}^{++}$) and $\mathrm{Na}_{2} \mathrm{MgEDTA}$ (which binds $\mathrm{Ca}^{++}$, but not $\mathrm{Mg}^{++}$) were used to investigate the divalent cation requirements for poly I-induced hemolysis. $\mathrm{Na}_{3} \mathrm{HEDTA}$ completely abolished poly I-induced hemolysis, whereas $\mathrm{Na}_{2} \mathrm{MgEDTA}$ diminished but did not destroy the capacity of poly I to enhance hemolysis of both PNHE and NHE (Table VI). These results indicate that these hemolytic systems display an absolute requirement for $\mathrm{Mg}^{++}$, but not for $\mathrm{Ca}^{++}$.

Effect of serum complement component or serum properdin depletion upon poly I-induced hemolysis. Since PNHE hemolysis is known to be dependent on all four components of $\mathrm{C}^{\prime}$ and properdin (8), and since poly $I$ is known to profoundly affect the $C^{\prime}$ system $(1,4,5)$, the ability of heat inactivated serum and of various $R$ reagents to support poly I-induced hemolysis was investigated. Serum heated at $56^{\circ} \mathrm{C}$ for $30 \mathrm{~min}-$ utes no longer supports red cell lysis even when poly $\mathrm{I}$ is added. In addition, treatment of serum so as to remove any one of the four major $C^{\prime}$ components renders such an $\mathrm{R}$ reagent devoid of the ability to support hemolysis of either PNHE 


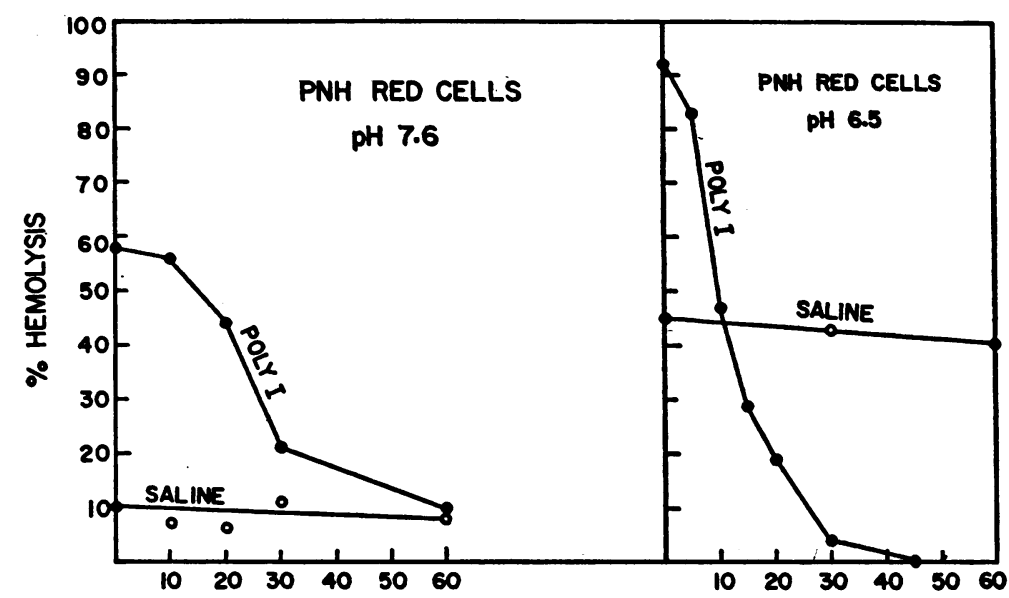

TIME (MIN.) OF PRE-EXPOSURE OF SERUM TO POLY I (OR SALINE)

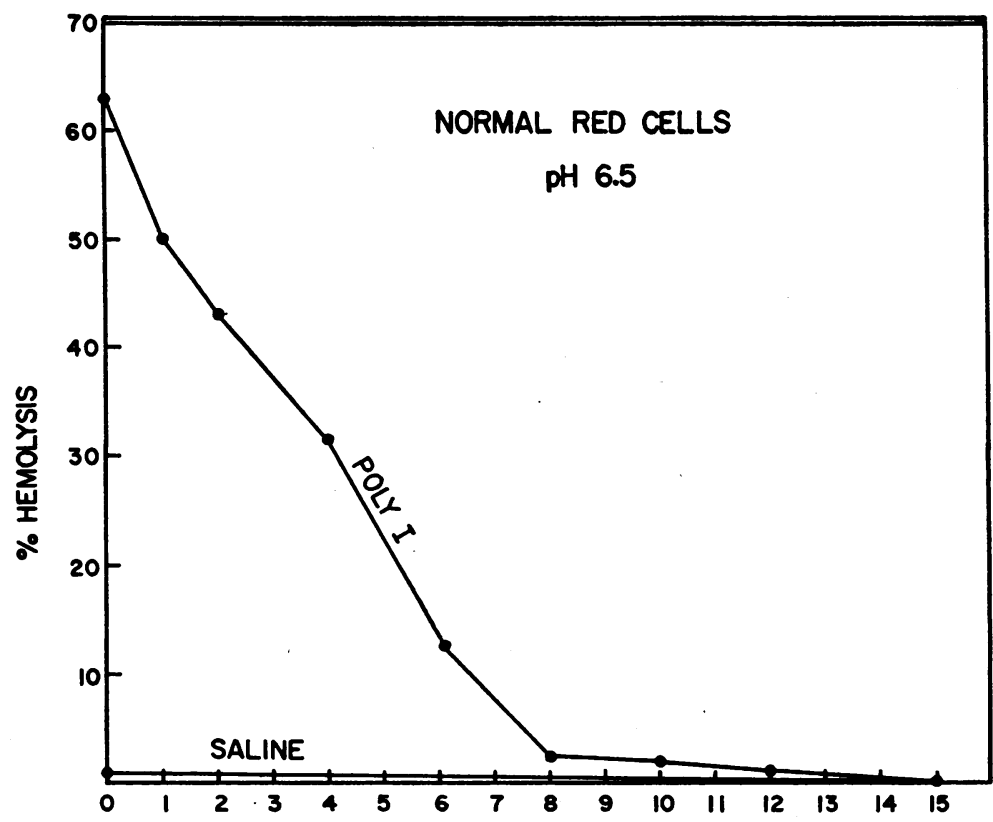

TIME (MIN.) OF PRE-EXPOSURE OF SERUM TO POLY I (OR SALINE)

FIG. 3. EFFECT OF PRE-EXPOSURE OF SERUM TO POLY I UPON THE CAPACTTY OF POLY I TO ENHANCE PNH RED CELL LYSIS (UPPER CURVES) OR INDUCE NORMAL RED CELL LYSIS (LOWER CURVE). One-tenth $\mathrm{ml}$ saline or poly I (1.0 $\mu$ mole P) was added to $1 \mathrm{ml}$ serum at the designated $\mathrm{pH}$. After the indicated time interval $0.05 \mathrm{ml}$ of a $20 \%$ suspension of red cells was added and the amount of hemolysis occurring at $37^{\circ} \mathrm{C}$ for 30 minutes determined.

or NHE, and the addition of poly I does not repair this deficiency (Table VII). The experiments involving NHE hemolysis in R4 were handicapped by the low level of control hemolysis observed with poly I addition, since this control was carried out at a serum dilution of $1: 1.45$ to correspond with the dilution of R4. From these experiments it seems likely that the ability of poly I to enhance or initiate red cell hemolysis is mediated through the $\mathrm{C}^{\prime}$ system, and in all likelihood is an earlier stage of the same process which, with the passage of time, leads to inactivation of the PNHE hemolytic system. Removal of properdin inhibits the capacity of serum to support PNHE 
TABLE III

Effect of pre-exposure of serum to various test materials upon their capacity to induce or enhance human red cell lysis

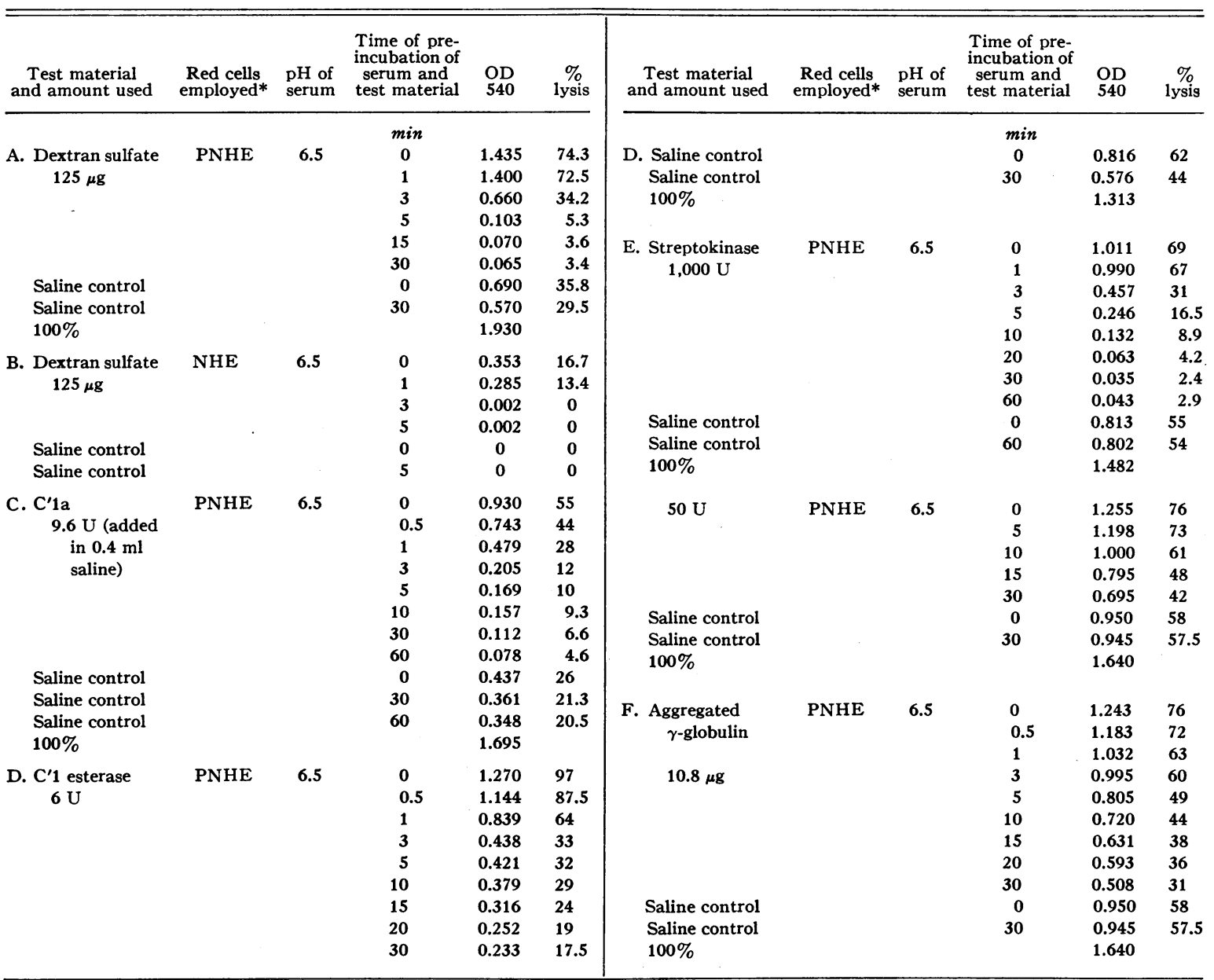

* PNHE = red cells from patients with paroxysmal nocturnal hemoglobinuria; NHE = normal human red cells.

hemolysis. The ability to hemolyze PNHE can but does not completely abolish, the ability of be restored to RP serum by the addition of poly poly I to provoke hemolysis of NHE (Table I; removal of properdin from serum diminishes, VIII).

TABLE IV

Effect of antigen-antibody precipitate upon the $P N H$ hemolytic system. The effect of an antigen-

Effect of serum dilution upon the enhancement of $P N H E$ hemolysis by $C^{\prime} 1$ esterase

\begin{tabular}{|c|c|c|c|c|}
\hline \multirow[b]{2}{*}{ Serum dilution } & \multicolumn{2}{|c|}{ Saline control } & \multicolumn{2}{|c|}{$C^{\prime} 1$ esterase } \\
\hline & $\begin{array}{l}\text { OD } \\
540\end{array}$ & $\begin{array}{c}\% \\
\text { lysis }\end{array}$ & $\begin{array}{l}\text { OD } \\
540\end{array}$ & $\begin{array}{c}\% \\
\text { lysis }\end{array}$ \\
\hline $\begin{array}{l}\text { Undiluted } \\
1: 1.2 \\
1: 1.4 \\
1: 1.6 \\
1: 1.8 \\
1: 2 \\
1: 3\end{array}$ & $\begin{array}{l}0.920 \\
0.922 \\
0.960 \\
0.950 \\
0.880 \\
0.798 \\
0.275\end{array}$ & $\begin{array}{l}49.1 \\
49.2 \\
51.3 \\
50.8 \\
47 \\
42.7 \\
14.7\end{array}$ & $\begin{array}{l}1.532 \\
1.417 \\
1.312 \\
1.037 \\
0.830 \\
0.655 \\
0.138\end{array}$ & $\begin{array}{l}82 \\
75.7 \\
70.2 \\
55.5 \\
44.3 \\
35 \\
7.4\end{array}$ \\
\hline $100 \%$ & 1.870 & & & \\
\hline
\end{tabular}

TABLE V

Effect of red cell storage upon susceptibility to poly I-induced lysis .

\begin{tabular}{ccc}
\hline & \multicolumn{2}{c}{$\%$ lysis (pH 6.5) } \\
\cline { 2 - 3 } Date of teṣt & Control & Poly I \\
\hline $3 / 23$ & 0 & 54 \\
$3 / 26$ & 0.6 & 63 \\
$3 / 30$ & 1.2 & 52 \\
$4 / 6$ & 1.1 & 61 \\
$4 / 13$ & 2.0 & 65 \\
$4 / 21$ & 0 & 64.5 \\
\end{tabular}




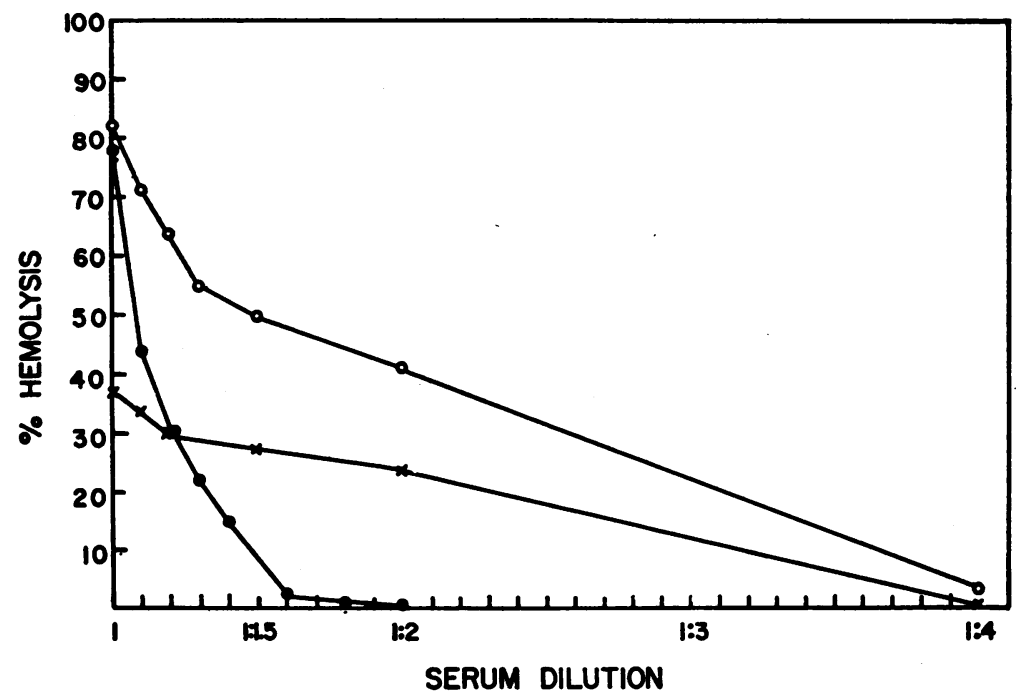

FIG. 4. EFFECT OF SERUM DILUTION UPON POLY I-INDUCED HEMOLYSIS. Serum ( $\mathrm{pH}$ 6.5) was diluted as indicated with $0.15 \mathrm{M} \mathrm{NaCl}$. One $\mu$ mole $\mathrm{P}$ poly I was employed as the stimulating test dose. The saline control for normal red cells showed no hemolysis and is therefore not plotted. $\mathrm{PNH}$ red cells-saline control, $X \longrightarrow X$; $\mathrm{PNH}$ red cells-poly I, $\mathrm{O}-\mathrm{O}$; normal red cells-poly I,

antibody precipitate on the PNHE hemolytic system was examined. No enhancement of PNHE hemolysis was observed over a wide dose range. Large amounts are capable of destroying serum factors involved in PNHE hemolysis progressively with the passage of time.

Effect of $C^{\prime} 1$ esterase serum inhibitor upon poly $I$ - and C'1-induced hemolysis. Two and threetenths $\mathrm{U}^{\prime} 1 \mathrm{EI}$ preadded to serum was incapable of preventing the enhancement or induction of hemolysis by poly I. Preincubation of $\mathrm{C}^{\prime} 1 \mathrm{a}$ or $C^{\prime} 1$ esterase with stoichiometric amounts of $C^{\prime} 1$ EI abolished their ability to enhance PNHE hemolysis.

\section{Discussion}

During classical immune lysis all the steps intermediate between coating of the cell with anti-

TABLE VI

Effects of various salts of EDTA upon poly I-induced hemolysis*

\begin{tabular}{|c|c|c|c|c|c|c|c|c|c|c|}
\hline \multirow[b]{3}{*}{ Test description } & \multirow{2}{*}{\multicolumn{6}{|c|}{ Test constituents }} & \multicolumn{4}{|c|}{ Results } \\
\hline & & & & & & & \multicolumn{2}{|c|}{ PNHE } & \multicolumn{2}{|c|}{ NHE } \\
\hline & $\begin{array}{l}20 \% \\
\text { red } \\
\text { cells }\end{array}$ & $\begin{array}{l}\text { Serum } \\
\text { pH } 6.5\end{array}$ & $\begin{array}{c}\text { Poly I } \\
10 \text { Pmoles } \\
\mathrm{P} / \mathrm{ml}\end{array}$ & $\underset{0.15 \mathrm{M}}{\mathrm{Na}_{\mathbf{2}} \mathrm{HEDTA}}$ & $\begin{array}{l}\mathrm{Na}_{2} \mathrm{MgEDTA} \\
0.15 \mathrm{M}\end{array}$ & Saline & $\begin{array}{l}\text { OD } \\
540\end{array}$ & $\begin{array}{c}\% \\
\text { lysis }\end{array}$ & $\begin{array}{l}\text { OD } \\
540\end{array}$ & $\begin{array}{c}\% \\
\text { lysis }\end{array}$ \\
\hline & $m l$ & $m l$ & $m l$ & $m l$ & $m l$ & $m l$ & $\mathrm{~m} \mu$ & & $\mathrm{m} \mu$ & \\
\hline Saline control & 0.05 & 1.0 & & & & 0.25 & 0.564 & 46 & 0.022 & 1.3 \\
\hline Poly I & 0.05 & 1.0 & 0.1 & & & 0.15 & 1.093 & 91 & 0.614 & 37 \\
\hline $\mathrm{Na}_{3} \mathrm{HEDTA}$ & 0.05 & 1.0 & & 0.15 & & 0.1 & 0.074 & 6.1 & 0.0 & 0 \\
\hline $\mathrm{Na}_{3} \mathrm{HEDTA}$ poly I & 0.05 & 1.0 & 0.1 & 0.15 & & & 0.066 & 5.5 & 0.0 & 0 \\
\hline $\mathrm{Na}_{2} \mathrm{MgEDTA}$ & 0.05 & 1.0 & & & 0.15 & 0.1 & 0.562 & 46 & 0.005 & 0.3 \\
\hline $\begin{array}{l}\mathrm{Na}_{2} \mathrm{MgEDTA} \\
\text { poly I }\end{array}$ & 0.05 & 1.0 & 0.1 & & 0.15 & & 0.960 & 80 & 0.350 & 21 \\
\hline Blank & & 1.0 & & & & 0.3 & & - & & \\
\hline $\begin{array}{l}100 \% \\
\text { (Freeze and thaw) }\end{array}$ & 0.05 & 1.0 & & & & 0.25 & 1.197 & & 1.665 & \\
\hline
\end{tabular}

* The final concentration of EDTA in the test mixtures is $1.7 \times 10^{-2} \mathrm{M}$. 
TABLE VII

Effect of complement component depletion upon poly I-induced hemolysis*

\begin{tabular}{|c|c|c|c|c|c|c|c|c|c|}
\hline & \multicolumn{9}{|c|}{ Reagent tested } \\
\hline & $\mathbf{R} \mathbf{1}$ & R1† + H.S. & R2 & R2† + H.S. & R3 & R4 & $\begin{array}{l}\text { Normal } \\
\text { serum }\end{array}$ & $\begin{array}{c}\text { Normalł } \\
\text { serum }\end{array}$ & $\begin{array}{c}\text { Normal } \\
\text { serum }\end{array}$ \\
\hline & \multicolumn{9}{|c|}{$\%$ hemolysis } \\
\hline PNHE saline & 3.7 & 1.9 & 1.2 & 5 & 1.2 & 5.5 & 43 & 42.5 & 40 \\
\hline PNHE poly I & 3.4 & 9.0 & 0 & 4 & 2.6 & 6.5 & 97.3 & 88 & 67 \\
\hline NHE saline & 4 & 0 & 0 & 1 & 1 & 1 & 0 & 1 & 1 \\
\hline NHE poly I & 1 & 4 & 0 & 1 & 3 & 1 & 54 & 26 & 9 \\
\hline
\end{tabular}

* Normal serum and $\mathrm{R}$ reagents from same $\mathrm{AB}$ serum pool. All tests performed at $\mathrm{pH}$ 6.5.

$\dagger$ Two parts $\mathrm{R}$ reagent +1 part heated serum (H.S.), $56^{\circ} \mathrm{C}, 30$ minutes.

$\$$ Normal serum diluted $1: 1.25$ with $0.15 \mathrm{M} \mathrm{NaCl}$; for comparison with $\mathrm{R} 1$.

$\S$ Normal serum diluted $1: 1.45$ with $0.15 \mathrm{M} \mathrm{NaCl}$; for comparison with $\mathrm{R} 4$.

body and actual $E^{*}$ formation occur at the cell surface (24). Thus the presence of oriented antibody molecules arranged in proper spatial conformation serves as a site of attachment for (11), and, through an allosteric mechanism, as an activator of, the $C^{\prime} 1$ molecule. The latter in turn proceeds to direct the attachment and in situ activation of $\mathrm{C}^{\prime} 4$ and $\mathrm{C}^{\prime} 2$, and so forth. The fact that the entire process occurs sequentially in direct apposition to the ultimate target for $\mathrm{C}^{\prime}$ action, the cell membrane, insures the greatest efficiency; in a sense the sensitized red cell surrounds itself with a halo of $\mathrm{C}^{\prime}$ activity. Although the availability of fluid phase $\mathrm{C}^{\prime}$ components for participation in this spatially localized sequence of events depends upon random phenomena, the sequential process of activation insures that all of the SA at which the entire sequence of $\mathrm{C}^{\prime}$ component attachment and activation occurs will result in S* formation.

Certain of the reactions that proceed at the cell membrane during the formation of $\mathrm{EAC}^{\prime}$. . . intermediates have their counterpart in events that can proceed entirely in the fluid phase. Thus it

TABLE VIII

Effect of properdin depletion upon the ability of poly I to induce or enhance human red cell lysis*

\begin{tabular}{lcc}
\hline \hline & \multicolumn{2}{c}{$\%$ hemolysis } \\
\cline { 2 - 3 } & NHE & PNHE \\
\hline RP serum + saline & Not done & 2 \\
RP serum + poly I (1 $\mu$ mole P) & 18 & 64 \\
Normal serum + poly I (1 $\mu$ mole P) & 49.5 & 81 \\
Normal serum + saline (control) & 0 & 51 \\
\hline
\end{tabular}

${ }^{*}$ The tests were performed at $\mathrm{pH} 6.5$. has long been recognized that purified activated $C^{\prime} 1$ or $C^{\prime} 1$ esterase attack fluid phase $C^{\prime} 4$ and $C^{\prime} 2$ $(12,25)$. Such an interaction has usually been detected by the fact that $\mathrm{C}^{\prime} 4$ and $\mathrm{C}^{\prime} 2$ are thus rendered hemolytically inert. However, recent evidence has indicated that $C^{\prime} 1$ esterase can, under appropriate conditions, enhance the activity of $\mathrm{C}^{\prime} 2$ in the fluid phase (25) presumably by a process analogous to the $C^{\prime} 2 \stackrel{C^{\prime} 1 a}{\longrightarrow} C^{\prime} 2 a$ conversion that occurs at the surface of an $\mathrm{EAC}_{1,4}^{\prime}$ complex (26).

The unique capacity of poly I alone of all the polynucleotides tested to enhance hemolysis of PNHE or to initiate hemolysis of NHE is reminiscent of the ability of this material, also unique, to serve as an anti-C' $C^{\prime}$ substance (1). In addition, the same maneuver that renders poly I incapable of interacting with whole $C^{\prime}(1), C^{\prime} 1$, or $C^{\prime} 1 q$ (4), and which destroys its capacity to evoke vascular permeability (6), helix formation with poly A or poly C, also destroys its capacity to enhance or induce hemolysis. Pre-exposure of red cells to any of the agents employed does not increase their susceptibility to hemolysis upon subsequent incubation with human serum; this suggests that the ability of these agents to stimulate hemolysis depends upon their interaction with serum components and not upon any capacity to attach to, sensitize, or alter the red cell. The failure of heatinactivated serum, or serum deficient in any one of the four major subcomponents of $C^{\prime}$, to support hemolysis in the presence of polyinosinic acid suggests that the serum components involved in poly I-induced hemolysis are those of the $\mathrm{C}^{\prime}$ system. Certainly the abolition of poly I-induced hemolysis by chelation of $\mathrm{Ca}^{++}$and $\mathrm{Mg}^{++}\left(\mathrm{Na}_{3}-\right.$ 
HEDTA) is consistent with $\mathrm{C}^{\prime}$ mediation, since the dependence of $\mathrm{C}^{\prime}$ activity on the presence of these cations has been amply demonstrated (27). The ability of poly I-induced hemolysis to proceed in the presence of $\mathrm{Na}_{2} \mathrm{MgEDTA}$ is disturbing since this chelating salt, which binds $\mathrm{Ca}^{++}$but not $\mathrm{Mg}^{++}$, has been shown to destroy the capacity of poly I to interact with the whole $C^{\prime}$ system (5). However, the latter observations were made in a dilute $C^{\prime}$ reagent. Subsequent studies in this laboratory have shown that the need for $\mathrm{Ca}^{++}$in immune lysis is not absolute; EA will undergo maximal lysis in undiluted human serum or in serum diluted 1:2 even in the presence of $\mathrm{Na}_{2}-$ MgEDTA (28). Apparently sufficient $C^{\prime} 1$ a can be generated under such circumstances to initiate and sustain the sequence of events leading to $C^{\prime}$ dependent hemolysis. Presumably, in undiluted human serum as a $C^{\prime}$ source, the dependence of the poly I-C'1 interaction upon $\mathrm{Ca}^{++}$is also not absolute.

Thus materials that under certain circumstances (immune lysis, dilute $\mathrm{C}^{\prime}$ ) act to inhibit $\mathrm{C}^{\prime}$-dependent lysis, under other circumstances (nonimmune lysis, undiluted $C^{\prime}$ ) act to enhance or initiate $C^{\prime}$-dependent hemolysis. The mechanism of inhibition of immune lysis by poly I, aggregated gamma globulin $(29,30)$, and streptokinase $(31$, 32) has been well established; dextran sulfate has been less carefully studied, but probably functions in a similar manner $(33,34)$. To explain the second phenomenon we have formulated the following hypothesis: the addition of these materials to serum initiates the evolution of fluid phase $C^{\prime} 1$ a. Although the $C^{\prime} 1 a$ thus formed is incapable of attaching to NHE (and probably to PNHE), both by virtue of the lack of a proper site of attachment on the cell (antibody), and through binding of the $\mathrm{C}^{\prime} 1 \mathrm{q}(11 \mathrm{~S})$ portion of the molecule (in the cases of aggregated $\gamma$-globulin and poly I), it can initiate a sequence of events involving the remainder of the fluid phase components of the $C^{\prime}$ system that results in red cell damage and hemolysis. This phase of the process, which might be termed the "activation" phase, can be extended to involve $\mathrm{C}^{\prime} 4$ and $\mathrm{C}^{\prime} 2$ on the basis of our current understanding of the mechanisms involved. A similar process of activation of fluid phase $C^{\prime} 3$ subcomponents $\left[\beta_{1 \mathrm{c}}\right.$-globulin
(35); $C^{\prime} 3 c, C^{\prime} 3 b(36)$ ] by $C^{\prime} 2 a$ in the presence of $\mathrm{Mg}^{++}$could then be postulated, with the ultimate appearance in the fluid phase of $\mathrm{C}^{\prime}$-dependent hemolytic factors. This process, with the passage of time, would be expected to dissipate itself, since at least one of the fluid phase reactions involved $\left(\mathrm{C}^{\prime} 2 \stackrel{\mathrm{C}^{\prime} 1 \mathrm{a}}{\longrightarrow} \mathrm{C}^{\prime} 2 \mathrm{a}\right)$, if allowed to proceed, finally results in the formation of a hemolytically inert form of C'2 (37). The recent observations of MüllerEberhard, Calcott, and Mardiney on the ability of cell-bound $C^{\prime} 2 \mathrm{a}$ to inactivate $\beta_{1 \mathrm{c}}$-globulin are also pertinent to this argument (38). This second phase, the "inactivation" phase, would explain the fact that with longer periods of preincubation of poly I and serum, the ability to initiate NHE lysis is lost and PNHE lysis is ultimately inhibited. Similar fluid phase events can both stimulate and inhibit classical immune hemolysis. Haines and Lepow have shown that properly chosen amounts of $C^{\prime} 1$ esterase can enhance the conversion of $\mathrm{EAC}_{1,4}^{\prime}$ to $\mathrm{EAC}_{1,4,2 \mathrm{a}}^{\prime}$ by $\mathrm{R} 3$. The efficiency of this enhancement diminishes as the period of $\mathrm{R} 3$ pre-exposure to $\mathrm{C}^{\prime} 1$ esterase is prolonged. With larger amounts of $C^{\prime} 1$ esterase, enhancement is entirely abolished and only inhibition is noted (25). We have chosen to describe these phenomena as the production of red cell membrane damage via "indifferent" activation of the $C^{\prime}$ system, since no antigen-antibody reaction specific for the red cell is involved. These hemolytic systems are clearly different from those reported by Neter and his co-workers $(20,39,40)$, by Boyden and Andersen (41), and by Middlebrook (42), since in these latter systems antigen (or antigenantibody complex) is capable of adsorbing to the red cell surface, and thus acts as a red cell sensitizer. In addition, these authors have all noted that normal serum in high concentration interferes with red cell adsorption of the sensitizing material (39-43). The hemolytic system described by Cowan (44) involving polyethylene glycol, guinea pig $C^{\prime}$, and sheep red cells is in many respects directly comparable to the present systems. Although red cells pre-exposed to polyethylene glycol and subsequently washed are not susceptible to hemolysis, the author postulates that polyethylene glycol acts as a red cell sensitizer since it forms a precipitate when mixed with an emulsion of Forssman hapten prepared from red 
cell stroma. At the same time the author notes the ability of polyethylene glycol to interact with $C^{\prime} 1$ when added to undiluted guinea pig serum; thus polyethylene glycol-induced hemolysis may well be effected through the mechanism outlined above. An analogous system involving in vitro damage to platelets by the $\mathrm{C}^{\prime}$ system initiated by an unrelated antigen-antibody reaction has recently been described (45). We have as yet failed to initiate a similar sequence of events vis-à-vis red cell damage by antigen-antibody precipitate. On the other hand, substantial confirmation of the theory presented has been achieved by use of partially purified $C^{\prime} 1 \mathrm{a}$ and $\mathrm{C}^{\prime} 1$ esterase, since addition of these materials to human serum will substantially enhance $\mathrm{PNH}$ hemolysis in the early phase of $C^{\prime} 1 \mathrm{a}$-serum contact, only to be followed by an "inactivation" phase similar in all respects to the phenomenon induced by poly I and the other test materials. Since $C^{\prime} 1$ esterase lacks a binding site and cannot induce $\mathrm{EAC}^{\prime}{ }_{1}$ formation $(3,25)$, the mechanism of its action must certainly be sought in relationship to fluid phase events.

The extreme sensitivity of test material-induced hemolysis to dilution may result from the fact that these systems, like the native PNHE hemolytic system, lack a mechanism for selectively and efficiently surrounding the cell, over an extended period, with those activated $\mathrm{C}^{\prime}$ components directly involved in membrane damage; instead, both systems depend upon random "hits" inflicted on the membrane by transiently activated fluid phase $C^{\prime}$ components. Jenkins, Christenson, and Engle have demonstrated that those PNHE resistant to hemolysis in the native acid hemolysis test have become coated with components of the $\mathrm{C}^{\prime}$ system (46). They have found that such cells react readily with anti- $\beta_{1 \mathrm{c}}$-globulin (anti-C'3) but not with anti- $\beta_{1 \mathrm{e}}(47)$-globulin (48) (anti-C'4). In this connection it is of interest that Rosen has recently shown, using $\mathrm{I}^{131}$-labeled $\beta_{1 \mathrm{c}}$-globulin, that the PNHE, in contrast to the NHE, has the capacity to coat itself with $\beta_{1 \mathrm{c}}$-globulin without the mediation of other fluid phase $C^{\prime}$ components (49). Such results imply that when the mechanism of red cell lysis by $C^{\prime}$ depends largely on fluid phase components, the late reacting $\mathrm{C}^{\prime}$ component may attach directly to the cell membrane.

If PNHE hemolysis is primarily dependent upon fluid phase, late-acting, $\mathrm{C}^{\prime}$ components, can one view $\mathrm{PNHE}$ as if they were red cell- $\mathrm{C}^{\prime}$ component intermediates? The fact that PNHE hemolyze in the presence of $\mathrm{Na}_{2} \mathrm{MgEDTA}$ might suggest that they are in the state $\mathrm{PNH}-\mathrm{EC}_{1}{ }_{1}$ or $\mathrm{PNH}-\mathrm{EC}^{\prime}{ }_{1,4}$. However, as mentioned earlier, EA will also hemolyze under similar conditions (28). In addition, after pre-exposure to $\mathrm{Na}_{3}$ HEDTA, a procedure that would elute any cell bound $C^{\prime} 1$ (50), PNHE show unaltered capacity to hemolyze in both native and $\mathrm{Na}_{2} \mathrm{MgEDTA}$ serum (28). PNHE will not hemolyze in R4 (8) nor in serum containing $\mathrm{Na}_{3}$ HEDTA (28), eliminating the possibility that they are in the state $\mathrm{PNH}_{-\mathrm{EC}^{\prime}}{ }_{4}$ or PNH-EC ${ }_{1,4,2}$. Thus, PNHE not only lack antibody, but in their native state also lack $\mathrm{C}^{\prime}$ component coats. The latter only appear after in vitro acid hemolysis (46), or possibly during severe hemolytic episodes in vivo, since the incidence of positive Coombs test appearing sometime during the course of the disease is higher than would be expected simply on the basis of random occurrence $(51,52)$.

Test material-induced hemolysis is more pronounced when carried out at $\mathrm{pH} 6.5$ than at $\mathrm{pH}$ 7.6 , and resembles in this respect the native PNHE hemolytic system. In addition, other $\mathrm{pH}$-dependent hemolytic systems such as are found in high titer cold agglutinin disease (53) and the in vitro hemolytic system involving artificially altered red cells (16) have been described. Recent studies in this laboratory have shown that the optimal $\mathrm{pH}$ for immune hemolysis is also 6.5 when human serum is the source of $C^{\prime}$ (54). Thus the fact that these several $\mathrm{C}^{\prime}$-dependent hemolytic systems function best at $\mathrm{pH} 6.5$ can no longer be used to distinguish between them and classical EA hemolysis. The relative $\mathrm{C}^{\prime} \mathrm{H}_{50}$ titer of a human $\mathrm{C}^{\prime}$ source when measured at $\mathrm{pH} 6.5$ is approximately 1.6 times that found at $\mathrm{pH} 7.5$; studies with $\mathrm{EAC}^{\prime}$. . . have shown that most of this increase can be attributed to the late phase reaction $\mathrm{EAC}_{1,4,2}^{\prime}+\mathrm{C}^{\prime} 3 \longrightarrow \mathrm{E}^{*}(54)$. The striking effect of $\mathrm{pH}$ change on the poly I-induced hemolysis of NHE can be better understood if one reasons that changing the $\mathrm{pH}$ from 6.5 to 7.6 is, in effect, like diluting the serum at $\mathrm{pH} 6.51$ : 1.6. In both instances hemolytic capacity is almost entirely lost. The stimulatory effect of $\mathrm{pH}$ alteration upon native PNHE hemolysis is different in 
mechanism from the effects of $C^{\prime} 1$ activators or $C^{\prime} 1$ esterase. Titrating serum from $\mathrm{pH} 7.6 \longrightarrow 6.5$ enhances its hemolytic potential, but serum kept at $\mathrm{pH} 6.5$ for extended periods does not display a pronounced "inactivation" phase. In addition, restoring the $\mathrm{pH}$ to 7.6 entirely abolishes the enhanced hemolytic potential both for PNHE cells and EA (54). We have concluded that PNHE hemolysis is, in a sense, a threshold phenomenon. The PNHE, injured in some unknown way, is extremely susceptible to $\mathrm{C}^{\prime}$-dependent injury. Normally, a small amount of fluid phase $C^{\prime}$-derived hemolytic potential may be present in serum by virtue of an intrinsic low-grade "activationinactivation" mechanism. Increasing the potency of the late-acting components of this intrinsic fluid phase system by lowering the $\mathrm{pH}$ suffices to lyse PNHE. NHE require either more intense fluid phase activation (poly I, dextran sulfate) or a membrane-localized $\mathrm{C}^{\prime}$ activation process (antibody), or both. PNHE also display their heightened sensitivity to $\mathrm{C}^{\prime}$-dependent hemolysis in the fluid phase-activated hemolytic systems and in $\mathrm{C}^{\prime}$-dependent lysis provoked in the usual way by a variety of red cell antibodies $(55,56)$.

Recognizing that red blood cells can be destroyed by the $\mathrm{C}^{\prime}$ system through the process of "indifferent" $\mathrm{C}^{\prime}$ activation implies that such a mechanism may initiate or exacerbate certain hemolytic anemias in man. Thus the well-known propensity of patients with acquired hemolytic anemia, including $\mathrm{PNH}$, to be worsened by bouts of intercurrent infection might be related to immune interactions between antibody and the invading agent or its products that indifferently activate the $C^{\prime}$ system. Indeed, such a mechanism might be sufficient to explain the pathogenesis of certain acquired hemolytic anemias in man. Lupus erythematosus, for example, is a disease in which acquired hemolytic anemia is a common finding (57). The similarity between the renal lesions in lupus patients and those produced by experimental hyperimmunization of rabbits is striking (58a). Christian, Hatfield, and Chase have recently shown that circulating antigen-antibody complexes may be present in the serum of lupus erythematosus patients (59); such complexes, acting in a fashion similar to poly $\mathrm{I}$, might result in $\mathrm{C}^{\prime}$ coating of, or injury to, red cells. Any Coombs-positive acquired hemolytic anemia wherein the red cell coating substance(s) is restricted to non-gamma (presumably $\mathrm{C}^{\prime}$ ) factors, where red cell antibodies are not demonstrable, is potentially caused by indifferent $\mathrm{C}^{\prime}$ activation (58b, 58c, 60). Paroxysmal nocturnal hemoglobinuria may be due entirely to such a mechanism. $C^{\prime}$ activation, perhaps by such complexes as have been recently described in a significant number of PNH patients (61), might be entirely responsible for all the manifestations of red cell injury, both in vivo and in vitro, seen in this disease. The demonstration that cells can suffer damage and destruction by the $\mathrm{C}^{\prime}$ system without the mediation of specific anticell antibody suggests that autoimmune mechanisms need not necessarily be invoked to explain the presence of $\mathrm{C}^{\prime}$ immunoglobulins on cells $(58 \mathrm{a}, 58 \mathrm{~b})$ or in tissue $(62$, 63).

\section{Summary}

The addition of polyinosinic acid (poly I) to a suspension of red cells from patients with paroxysmal nocturnal hemoglobinuria $(\mathrm{PNH})$ in undiluted normal human serum results in pronounced stimulation of red cell lysis. In addition poly I, under similar circumstances, will initiate substantial hemolysis of normal human red cells. Poly I loses the ability to induce hemolysis if it is combined with polyadenylic or polycytidylic acids to form a hydrogen bonded helical structure. The $\mathrm{pH}$ optimum for poly I-induced hemolysis is 6.5. Exposure of red cells to poly I, followed by thorough washing, does not result in increased red cell hemolysis when the cells are subsequently added to serum. Exposure of serum to poly I for increasing periods of time results in progressive decrease in the amount of hemolysis produced upon subsequent addition of red cells. Serum pre-exposed to poly I ultimately loses the ability to support any hemolysis of PNH red cells. Poly Iinduced hemolysis is rapidly lost upon slight dilution of serum, but is not affected by prolonged in vitro storage of red cells. Poly I-induced hemolysis is abolished by addition to serum of $\mathrm{Na}_{3}$ HEDTA, but is not affected by $\mathrm{Na}_{2} \mathrm{MgEDTA}$. Removal from serum of any one of the four major components of complement abolishes its capacity to support poly I-induced hemolysis. Removal of properdin from serum only partially reduces its capacity to support poly I-induced hemolysis. 
Other activators of the first component of complement $\left(C^{\prime} 1\right)$ such as dextran sulfate, streptokinase, and aggregated gamma globulin, as well as activated $C^{\prime} 1$ and $C^{\prime} 1$ esterase, can enhance $P N H$ red cell lysis in a similar fashion. Dextran sulfate can also induce normal red cell lysis. These hemolytic systems are presumed to result from the evolution in the fluid phase of hemolytically active, late-acting, labile complement components, capable of injuring red cell membrane despite the lack of an antibody coat. The observation that "indifferent" complement activation can result in red cell damage may be pertinent to concepts regarding the pathogenesis of certain acquired hemolytic anemias in man.

\section{Acknowledgments}

These studies would not have been possible without the cooperation of Dr. Frank H. Gardner, Peter Bent Brigham Hospital, Boston, Mass., who supplied us with $\mathrm{PNH}$ red cells from four patients over a period of many months. We are also deeply grateful to Dr. Robert C. Hartmann, Hematology Service, Vanderbilt University School of Medicine, Nashville, Tenn., for allowing us to study red cells from six PNH patients. Drs. C. F. Hinz, Jr., and J. Pensky of Western Reserve University College of Medicine, Cleveland, Ohio, were kind enough to supply us with $C^{\prime} 1$ esterase serum inhibitor.

\section{References}

1. Yachnin, S. Biologic properties of polynucleotides. I. The anticomplementary activity of polynucleotides. J. clin. Invest. 1963, 42, 1947.

2. Yachnin, S., and D. Rosenblum. Biologic properties of polynucleotides. IV. Studies on the mechanism of complement inhibition by polyinosinic acid together with observations on the in vivo effect of polyinosinic acid on complement activity. J. clin. Invest. 1964, 43, 1175.

3. Lepow, I. H., G. B. Naff, E. W. Todd, J. Pensky, and C. F. Hinz, Jr. Chromatographic resolution of the first component of human complement into three activities. J. exp. Med. 1963, 117, 983.

4. Yachnin, S., D. Rosenblum, and D. Chatman. Biologic properties of polynucleotides. V. Studies on the inhibition of the first component of complement by polyinosinic acid; the interaction with $\mathrm{C}^{\prime} 1 \mathrm{q}$. J. Immunol. 1964, 93, 540.

5. Yachnin, S., D. Rosenblum, and D. Chatman. Biologic properties of polynucleotides. VI. Further studies on the mechanism of complement inhibition by polyinosinic acid: the inactivation of the fourth component of complement. J. Immunol. 1964, 93, 549.
6. Yachnin, S., and J. M. Ruthenberg. Biologic properties of polynucleotides. VII. Vascular permeability in guinea pig skin induced by polyinosinic acid. J. Immunol. 1965, 94, in press.

7. Ratnoff, O. D., and I. H. Lepow. Complement as a mediator of inflammation; enhancement of vascular permeability by purified human $C^{\prime} 1$ esterase. J. exp. Med. 1963, 118, 681.

8. Hinz, C. F., Jr., W. S. Jordan, Jr., and L. Pillemer. The properdin system and immunity. IV. The hemolysis of erythrocytes from patients with paroxysmal nocturnal hemoglobinuria. J. clin. Invest. 1956, 35, 453.

9. Kabat, E. A., and M. M. Mayer. Experimental Immunochemistry. Springfield, Ill., Charles C Thomas, 1961, p. 162 ; (a) p. 163.

10. Pillemer, L., L. Blum, I. H. Lepow, O. A. Ross, E. W. Todd, and A. C. Wardlaw. The properdin system and immunity. I. Demonstration and isolation of a new serum protein, properdin, and its role in immune phenomena. Science 1954, 120, 279.

11. Hinz, C. F., Jr., and A. M. Mollner. Studies on immune human hemolysis. III. Role of $11 \mathrm{~S}$ component in initiating the Donath-Landsteiner reaction. J. Immunol. 1963, 91, 512.

12. Lepow, I. H., O. D. Ratnoff, F. S. Rosen, and L. Pillemer. Observations on a pro-esterase associated with partially purified first component of human complement $\left(C^{\prime} 1\right)$. Proc. Soc. exp. Biol. (N. Y.) 1956, 92, 32.

13. Levy, L. R., and I. H. Lepow. Assay and properties of serum inhibitor of $C^{\prime} 1$-esterase. Proc. Soc. exp. Biol. (N. Y.) 1959, 101, 608.

14. Haines, A. L., and I. H. Lepow. Studies on human C'1-esterase. I. Purification and enzymatic properties. J. Immunol. 1964, 92, 456.

15. Pensky, J., L. R. Levy, and I. H. Lepow. Partial purification of a serum inhibitor of $\mathrm{C}^{\prime} 1$-esterase. J. biol. Chem. 1961, 236, 1674.

16. Yachnin, S., M. T. Laforet, and F. H. Gardner. $\mathrm{pH}$ dependent hemolytic systems. I. Their relationship to paroxysmal nocturnal hemoglobinuria. Blood 1961, 17, 83.

17. Yachnin, S., and F. H. Gardner. Measurement of human erythrocyte neuraminic acid: relationship to haemolysis and red blood cell virus interaction. Brit. J. Haemat. 1961, 7, 464.

18. Hinz, C. F., Jr., R. Weisman, Jr., and T. H. Hurley. Paroxysmal nocturnal hemoglobinuria; relationship of in vitro and in vivo hemolysis to clinical severity. J. Lab. clin. Med. 1956, 48, 495.

19. Hewitt, B. R. Spectrophotometric determination of protein in alkaline solution. Nature (Lond.) 1958, 182, 246.

20. Neter, E., L. F. Bertram, D. A. Zak, M. R. Murdock, and C. E. Arbesman. Studies on hemagglutination and hemolysis by Escherichia coli antisera. J. exp. Med. 1952, 96, 1. 
21. Hinz, C. F., Jr., J. Abraham, and L. Pillemer. Requirement for properdin in hemolysis of human erythrocytes treated with tannic acid. Proc. Soc. exp. Biol. (N. Y.) 1957, 94, 230.

22. Dacie, J. V., M. C. G. Israëls, and J. F. Wilkinson. Paroxysmal nocturnal hemoglobinuria of the Marchiafava-type. Lancet 1938, 1, 390.

23. Ozer, F. L., and H. Chaplin, Jr. Agglutination of stored erythrocytes by a human serum. Characterization of the serum factor and erythrocyte changes. J. clin. Invest. 1963, 42, 1735.

24. Austen, K. F., and Z. A. Cohn. Contribution of serum and cellular factors in host defense reactions. I. Serum factors in host resistance. New Engl. J. Med. 1963, 268, 933.

25. Haines, A. L., and I. H. Lepow. Studies on human $C^{\prime} 1$-esterase. II. Function of purified C'1-esterase in the human complement system. J. Immunol. 1964, 92, 468.

26. Stroud, R. M., K. F. Austen, and M. M. Mayer. Immune hemolysis: kinetics of enzymatic activation and fixation of $C^{\prime} 2$ by activated $C^{\prime} 1$ ( $\left.C^{\prime} 1 a\right)$. Fed. Proc. 1963, 22, 613.

27. Levine, L., A. G. Osler, and M. M. Mayer. Studies on the role of $\mathrm{Ca}^{++}$and $\mathrm{Mg}^{++}$in complement fixation and immune hemolysis. III. The respective roles of $\mathrm{Ca}^{++}$and $\mathrm{Mg}^{++}$in immune hemolysis. J. Immunol. 1953, 71, 374.

28. Yachnin, S., and J. M. Ruthenberg. Role of calcium in complement dependent hemolysis. Proc. Soc. exp. Biol. (N. Y.) 1964, 117, 179.

29. Christian, C. L. Studies of aggregated $\boldsymbol{\gamma}$-globulin. I. Sedimentation, electrophoretic and anticomplementary properties. J. Immunol. 1960, 84, 112.

30. Marcus, D. M. A study of the mechanism of the anticomplementary activity of $\boldsymbol{\gamma}$-globulin. J. Immunol. 1960, 84, 273.

31. Lepow, I. H., L. Wurz, O. D. Ratnoff, and L. Pillemer. Studies on the mechanism of inactivation of human complement by plasmin and by antigenantibody aggregates. I. The requirement for a factor resembling $\mathrm{C}^{\prime} 1$ and the role of $\mathrm{Ca}^{++}$. J. Immunol. 1954, 73, 146.

32. Lepow, I. H., and L. Pillemer. Studies on the mechanism of inactivation of human complement by plasmin and by antigen-antibody aggregates. II. Demonstration of two distinct reaction stages in complement fixation. J. Immunol. 1955, 75, 63.

33. Taylor, C. E. D., and K. W. Walton. The molecular characteristics determining the anticomplementary activity of dextran sulfates. Brit. J. exp. Path. 1957, 38, 248.

34. Mutsaars, W., and L. Lison. Recherches concernant l'alexine. III. Action des esters sulfuriques polysaccharidiques. Effet antagoniste des colorants basiques. Ann. Inst. Pasteur 1948, 74, 40.

35. Müller-Eberhard, H. J., and U. Nilsson. Relation of of $\beta_{1}$-glycoprotein of human serum to the complement system. J. exp. Med. 1960, 111, 217.
36. Linscott, W. D., and K. Nishioka. Components of guinea pig complement. II. Separation of serum fractions essential for immune hemolysis. J. exp. Med. 1963, 118, 795.

37. Mayer, M. M., E. T. Asher, and T. Borsos. Inhibition of guinea pig $\mathrm{C}^{\prime} 2$ by rabbit-anti-C'2. Fed. Proc. 1962, 21, 17.

38. Müller-Eberhard, H. J., M. A. Calcott, and M. R.

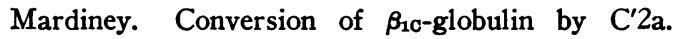
Fed. Proc. 1964, 23, 506.

39. Gorzynski, E. A., H. Brodhage, and E. Neter. Hemagglutination by mixtures of enterobacterial antigen and Shigella sonnei antiserum. Z. Hyg. Infekt.- Kr. 1964, 150, 1.

40. Neter, E. Attachment of antibodies and antigens onto cell surfaces in Cell-Bound Antibodies, Conference of the National Academy of SciencesNational Research Council, held May 10, 1963, in Washington, D. C. Philadelphia, Wistar Institute Press, 1963, p. 35.

41. Boyden, S. V., and M. E. Andersen. Agglutination of normal erythrocytes in mixtures of antibody and antigen, and haemolysis in the presence of complement. Brit. J. exp. Path. 1955, 36, 162.

42. Middlebrook, G. Antigens of tubercle bacillus involved in hemagglutination and hemolysis reactions. Bull. N. Y. Acad. Med. 1952, 28, 474.

43. Neter, E., O. Westphal, and O. Lüderitz. Effects of lecithin, cholesterol, and serum on erythrocyte modification and antibody neutralization by enterobacterial lipopolysaccharides. Proc. Soc. exp. Biol. (N. Y.) 1955, 88, 339.

44. Cowan, K. M. Lysis of sheep erythrocytes by a long-chain polymer, polyethylene glycol, and complement. Dissertation submitted to the School of Hygiene and Public Health of the Johns Hopkins University, Baltimore, Maryland, 1954.

45. Gocke, D. J. In vitro studies of the plasma requirement in platelet damage by an unrelated antigen-antibody reaction. Fed. Proc. 1964, 23, 404.

46. Jenkins, D. E., Jr., W. N. Christenson, and R. L. Engle, Jr. Erythrocyte complement coating in the acid hemolysin and thrombin tests of paroxysmal nocturnal hemoglobinuria (abstract). Blood 1962, 20, 788.

47. Müller-Eberhard, H. J., and C. E. Biro. Isolation and description of the fourth component of human complement. J. exp. Med. 1963, 118, 447.

48. Jenkins, D. E., Jr. Personal communication.

49. Rosen, F. Personal communication.

50. Becker, E. L. Concerning the mechanism of complement action. V. The early steps in immune hemolysis. J. Immunol. 1960, 84, 299.

51. Crosby, W. H. Paroxysmal nocturnal hemoglobinuria. Relation of the clinical manifestations to underlying pathogenic mechanisms. Blood 1953, 8, 769.

52. Dameshek, W., and H. Fudenberg. Paroxysmal 
nocturnal hemoglobinuria. Atypical manifestations suggesting an immunologic disease. Arch. intern. Med. 1957, 99, 202.

53. Dacie, J. V. The presence of cold hæmolysins in sera containing cold hæmagglutinins. J. path. Bact. 1950, 62, 241.

54. Yachnin, S., and J. M. Ruthenberg. pH optima in immune hemolysis; a comparison between guinea pig and human complement. J. clin. Invest. 1965, 44, 149.

55. Dacie, J. V. The Haemolytic Anaemias, Congenital and Acquired. London, J. and A. Churchill, Ltd., 1954 , p. 425.

56. Ham, T. H., and J. H. Dingle. Studies on destruction of red blood cells. II. Chronic hemolytic anemia with paroxysmal nocturnal hemoglobinuria: certain immunological aspects of the hemolytic mechanism with special reference to serum complement. J. clin. Invest. 1939, 18, 657.

57. Wintrobe, M. M. Clinical Hematology, 5th ed. Philadelphia, Lea \& Febiger, 1961, p. 613.

58. Immunopathology. Third International Symposium, P. Grabar and P. A. Mieschler, Eds. New York, Grune \& Stratton, 1963. (a) J. D. Feldman. Pathogenesis of ultrastructural glomerular changes induced by immunologic means, p. 263; (b) J. P. Leddy, R. W. Hill, S. N. Swisher, and J. H. Vaughn. Observations on the immunochemical nature of red cell autosensitization, p. 318; (c) H. J. Müller-Eberhard. Identification of complement antigens coating red cells in acquired hemolytic anemia, p. 332.

59. Christian, C. L., W. B. Hatfield, and P. H. Chase. Systemic lupus erythematosus. Cryoprecipitation of sera. J. clin. Invest. 1963, 42, 823.

60. Dacie, J. V. The Haemolytic Anaemias Congenital and Acquired. Part II. The Auto-Immune Haemolytic Anaemias, 2nd ed. New York, Grune \& Stratton, 1962, p. 429.

61. Kaplan, M. E., S. Kochwa, L. R. Wasserman, and R. E. Rosenfield. Circulating antiglobulins in paroxysmal nocturnal hemoglobinuria (PNH) (abstract). Clin. Res. 1964, 12, 236.

62. Lachmann, P. J., H. J. Müller-Eberhard, H. G. Kunkel, and F. Paronetto. The localization of in vivo bound complement in tissue sections. J. exp. Med. 1962, 115, 63.

63. Freedman, P., and A. S. Markowitz. Gamma globulin and complement in the diseased kidney. J. clin. Invest. 1962, 41, 328. 